\title{
Psihosocialne značilnosti učencev kot napovedniki različnih oblik medvrstniške viktimizacije in nasilnega vedenja
}

\author{
Katja Koširi" ${ }^{*}$ Tina Pivec ${ }^{2}$, Lucia Klasinc ${ }^{3}$, Tanja Špes ${ }^{4}$ in Marina Horvat ${ }^{1}$ \\ ${ }^{1}$ Oddelek za psihologijo, Filozofska fakulteta, Univerza v Mariboru \\ ${ }^{2}$ Pedagoški inštitut, Ljubljana \\ ${ }^{3}$ Pedagoška fakulteta, Univerza v Mariboru \\ ${ }^{4}$ Zgornje Prebukovje
}

\begin{abstract}
Povzetek: Sodobne razlage medvrstniškega nasilja kot enega ključnih vidikov, ki prispeva k razvoju dinamike medvrstniškega nasilja, predpostavljajo psihosocialne značilnosti učencev. Namen raziskave je bil preveriti zaznano oporo vrstnikov in učiteljev, socialno samopodobo, prijateljske odnose in zaznano priljubljenost kot napovednike telesne, besedne in odnosne viktimizacije ter izvajanja telesnega, besednega in odnosnega nasilja ter morebitno moderatorsko vlogo spola v tem odnosu. Ob tem smo želele preučiti tudi, ali zaznana opora učiteljev pojasnjuje dodaten delež variance v viktimizaciji in nasilnem vedenju, ki ga ni mogoče pojasniti s psihosocialnimi značilnostmi učencev. V raziskavi je sodelovalo 1905 učencev (49,9 \% fantov) z 22 osnovnih šol. Za merjenje nasilja in viktimizacije so bile uporabljene tako mere samoporočanja kot mere vrstniških nominacij, psihosocialne značilnosti učencev so bile operacionalizirane bodisi kot samoocena bodisi kot mere vrstniških nominacij (prijateljstvo, priljubljenost). Rezultati so pokazali, da so napovedniki podobni za različne oblike viktimizacije; enako velja tudi za različne oblike nasilja. Zaznana opora vrstnikov in socialna samopodoba napovedujeta vse tri oblike viktimizacije. Starost učencev, s strani vrstnikov zaznana priljubljenost ter zaznana opora učiteljev napovedujejo vse tri oblike izvajanja nasilja. Spol učencev se kaže kot moderator odnosov med zaznano oporo učiteljev ter med besedno viktimizacijo ter med telesnim in besednim nasiljem; zaznana opora učiteljev je tako varovalni dejavnik proti besedni viktimizaciji le za dekleta ter proti izvajanju besednega in telesnega nasilja le za fante. Fantje, ki zaznavajo manj opore vrstnikov in ki imajo nižjo socialno samopodobo, poročajo o več telesne viktimizacije; dekleta, ki jih vrstniki zaznavajo kot bolj priljubljene v razredu, poročajo o več besedne viktimizacije.
\end{abstract}

Ključne besede: viktimizacija, medvrstniško nasilje, vrstniški odnosi, odnosi z učitelji, samopodoba

\section{Students' psychosocial characteristics as predictors of different forms of victimization and bullying}

\author{
Katja Košir ${ }^{*}$, Tina Pivec ${ }^{2}$, Lucia Klasinc ${ }^{3}$, Tanja Špes ${ }^{4}$ and Marina Horvat ${ }^{1}$ \\ ${ }^{1}$ Department of Psychology, Faculty of Arts, University of Maribor, Slovenia \\ ${ }^{2}$ Educational Research Institute, Ljubljana, Slovenia \\ ${ }^{3}$ Faculty of Education, University of Maribor, Slovenia \\ ${ }^{4}$ Zgornje Prebukovje, Slovenia
}

\begin{abstract}
Students' psychosocial characteristics are conceptualized as one of the crucial aspects that contribute to the bullying dynamics. The aim of the study was to examine perceived peer and teacher support, social self-concept, friendships and perceived popularity as predictors of physical, verbal and relational victimization and bullying and the possible moderator role of gender in these relationships. In addition, the incremental predictive role of perceived teachers' support with regard to measures of peer relations for different forms of victimization and bullying was examined. 1905 students ( $49.9 \%$ boys) from 22 elementary schools participated in the study. Self-report as well as peer nomination measures were used to assess victimization and bullying. Students' psychosocial characteristics were operationalized as either self-report measures or as peer nomination measures (friendship, popularity). The results indicated similar predictors for different forms of victimization as well as bullying. Perceived peer support and social selfconcept predicted all three forms of victimization. Students' age, peer perceived popularity, and perceived teachers' support were significant predictors for all three forms of bullying. Students' gender was found to moderate the relationship between perceived teacher support and verbal victimization as well as physical and verbal bullying; perceived teacher support represents a protective factor against verbal victimization only for girls and against verbal and physical bullying behavior only for boys. Boys that perceive less peer support and have lower social self-concept report higher levels of physical victimization; girls that are perceived as more popular by their peers report higher levels of verbal victimization.
\end{abstract}

Keywords: victimization, bullying, peer relations, teacher-student relations, self-concept

\footnotetext{
*Naslov/Address: izr. prof. dr. Katja Košir, Oddelek za psihologijo, Filozofska fakulteta, Univerza v Mariboru, Koroška cesta 160, 2000 Maribor, e-mail: katja.kosir@um.si
}

Članek je licenciran pod pogoji Creative Commons Attribution 4.0 International licence. (CC-BY licenca). The article is licensed under a Creative Commons Attribution 4.0 International License (CC-BY license). 
Poznavanje dejavnikov, ki sodoločajo verjetnost, da učenec postane bodisi žrtev bodisi izvajalec medvrstniškega nasilja, je ključno za oblikovanje učinkovitih strategij preprečevanja in odzivanja nanj. Pretekle raziskave (za pregled glej npr. Menesini in Salmivalli, 2017) so pokazale, da sta tako viktimizacija kot nasilno vedenje $\mathrm{v}$ odnosu do vrstnikov pojava z zelo raznolikimi dejavniki, ki povečujejo ali zmanjšujejo verjetnost posameznikove vključenosti $\mathrm{v}$ proces medvrstniškega nasilja bodisi kot žrtve bodisi kot izvajalca nasilja. Pri preučevanju medvrstniškega nasilja v šolskem kontekstu lahko dejavnike razdelimo na dejavnike na ravni šole (npr. delež fantov na šoli, šolska klima; Ma, 2002), razreda (npr. razredne norme v zvezi z nasilneži in žrtvami; Nocentini, Menesini in Salmivalli, 2013; Salmivalli, Voeten in Poskiparta, 2011) in na ravni posameznika. Čeprav so za celostno razumevanje pojava medvrstniškega nasilja pomembni dejavniki na vseh omenjenih ravneh, so najmočnejši napovedniki tako medvrstniške viktimizacije kakor nasilja vendarle dejavniki na individualni ravni (Bradshaw, Sawyer in O’Brennan, 2009; Kärnä idr., 2011; Saarento, Kärnä, Hodges in Salmivalli, 2013). Ob tem so raziskovalci na področju medvrstniškega nasilja $v$ zadnjih dveh desetletjih izpostavili ključno vlogo socialne opore v razredu za razvoj medvrstniškega nasilja; nizka stopnja vrstniške opore se je v preteklih raziskavah pokazala kot dejavnik tveganja za razvoj viktimizacije (Salmivalli in Peets, 2011), obenem pa naj bi bila za posameznike $\mathrm{z}$ višjo stopnjo nasilnega vedenja značilna relativno visoka stopnja vrstniške opore in visoka stopnja priljubljenosti (Salmivalli, Huttonen in Lagerspetz, 1997; Vaillancourt, Hymel in McDougal, 2003). Manj jasna in manj raziskana je vloga opore učiteljev v dinamiki medvrstniškega nasilja (Karlsson, Stickley, Lindblad, Schwab-Stone in Ruchkin, 2014). Obenem je večina raziskav viktimizacijo in nasilje opredeljevala kot enotna konstrukta in ni ločevala med različnimi pojavnimi oblikami viktimizacije in nasilja, čeprav so rezultati nekaterih raziskav (npr. Card, Stucky, Sawalani in Little, 2008) nakazali, da se utegnejo napovedniki različnih oblik viktimizacije in nasilnega vedenja razlikovati.

V pričujoči raziskavi smo zato želele preučiti psihosocialne dejavnike različnih oblik vrstniške viktimizacije in nasilnega vedenja pri učencih v obdobju zgodnjega mladostništva, pri čemer smo izhajale iz uveljavljene delitve medvrstniškega nasilja na telesno, besedno in odnosno nasilje (Salmivalli in Peets, 2011; Sanders in Phye, 2004). Ključni cilj raziskave je bil preveriti vlogo različnih vidikov vrstniških odnosov posameznih učencev (zaznana opora vrstnikov, s strani vrstnikov zaznana priljubljenost, prijateljski odnosi, socialna samopodoba) pri napovedovanju različnih oblik nasilja in viktimizacije. Dodatno smo želele ugotoviti, ali zaznana opora učiteljev pojasnjuje dodaten delež variance v merah vrstniške viktimizacije in nasilja, ki ga ne pojasnjujejo mere vrstniških odnosov ter preveriti, ali spol predstavlja moderator odnosa med merami vrstniških odnosov in opore učiteljev ter različnimi oblikami medvrstniške viktimizacije in nasilja. Psihosocialne značilnosti učencev, ki smo jih kot napovednike viktimizacije in nasilja vključile $\mathrm{v}$ raziskavo, predstavljajo oceno različnih vidikov socialnega delovanja učencev in temeljijo tako na samooceni (zaznana opora, samopodoba) kot na poročanju vrstnikov (prijateljstvo, priljubljenost).

\section{Vloga socialne opore $\mathbf{v}$ dinamiki medvrstniškega nasilja: psihosocialni dejavniki viktimizacije in nasilnega vedenja}

Prepoznavanje medvrstniškega nasilja zaradi raznolikosti pojavnih oblik medvrstniškega nasilja kakor tudi zaradi večplastnosti dinamike tega socialnega procesa predstavlja zelo kompleksno nalogo. Avtorji medvrstniško nasilje običajno delijo na telesno, besedno in odnosno, pri čemer kot posebno obliko nasilja izpostavljajo spletno nasilje (glej npr. Salmivalli in Peets, 2011; Sanders in Phye, 2004).

Sodobne opredelitve medvrstniškega nasilja izhajajo iz Olweusove (1993) opredelitve in poudarjajo tri ključne značilnosti medvrstniškega nasilja: (1) negativna dejanja so namerno povzročena, gre torej za proaktivno, neizzvano obliko agresivnega vedenja; (2) ta sovražna dejanja do žrtve se ponavljajo in (3) med nasilnežem in žrtvijo obstaja neravnovesje moči (psihične ali telesne) (Saarento, Garandeau in Salmivalli, 2015). Ob tem sodobnejši avtorji (npr. Orpinas in Horne, 2006; Salmivalli in Peets, 2011; Sanders in Phye, 2004) opozarjajo, da je medvrstniško nasilje $v$ večini primerov javni dogodek, ki presega odnos med nasilnežem in žrtvijo. Gre za pojav, v katerem sodeluje celotna socialna skupina (torej najpogosteje razred), pri čemer ima vedenje vrstnikov kot opazovalcev pomembno vlogo pri pojavljanju in vzdrževanju medvrstniškega nasilja: njihovo odzivanje na pojav medvrstniškega nasilja ima potencial, da deluje preventivno ali pa nasilje spodbuja. Ključni motiv izvajalcev medvrstniškega nasilja je namreč ravno socialna moč, ki jo s tem pridobijo (Olthof, Goossens, Vermande, Aleva in van der Maulen, 2011; Salmivalli, 2014), opazovalci (vrstniki) pa so tisti, ki izvajalcu nasilja socialno moč podelijo ali odrečejo.

Sodobne raziskave dejavnike medvrstniškega nasilja in viktimizacije pretežno iščejo $\mathrm{v}$ značilnostih vrstniškega konteksta ter v odnosih z učitelji. Raziskave (npr. Olthof idr., 2011; Saarento idr., 2013; Salmivalli, 2014) nakazujejo, da je eden ključnih vidikov, ki so pomembni za razumevanje dinamike medvrstniškega nasilja, neravnovesje socialne moči med nasilnežem in žrtvijo, socialno moč pa posamezniku podeljuje kvantiteta in kvaliteta odnosov, ki jih vzpostavlja; $\mathrm{V}$ šolskem kontekstu so to pretežno odnosi $\mathrm{z}$ vrstniki in $\mathrm{z}$ učitelji. Učenci $\mathrm{z}$ visoko stopnjo nasilnega vedenja so tako s strani vrstnikov pogosteje zaznani kot priljubljeni, kar ne drži za učence $\mathrm{z}$ visoko stopnjo viktimizacije (De Bruyn, Cillessen in Wissink, 2010; Veenstra idr., 2005). Raziskave (npr. Boulton, Trueman, Chau, Whitehand in Amatya, 1999; Hodges, Boivin, Vitaro in Bukowski, 1999) so pokazale, da predstavlja posedovanje podpornih odnosov v razredu enega od ključnih varovalnih dejavnikov nadaljnje viktimizacije. Nadalje so Sainio, Veenstra, Huitsing in Salmivalli (2011) poročali, da žrtve medvrstniškega nasilja, ki zaznavajo oporo s strani vrstnikov, kažejo boljšo psihološko prilagojenost in poročajo o višjem samospoštovanju. Metaanalitična raziskava avtorjev Cook, Williams, Guerra, Kim in Sadek (2010) pa je pokazala, da se učenci $\mathrm{z}$ visoko stopnjo nasilnega vedenja zaznavajo kot visoko socialno kompetentne, medtem ko se visoko viktimizirani učenci zaznavajo kot nizko socialno kompetentne ter imajo nizek socialni položaj med vrstniki. 
Nadalje raziskave kažejo, da so tudi odnosi med učitelji in učenci pomemben dejavnik dinamike medvrstniškega nasilja. Dosedanje raziskave so kakovost odnosov med učitelji in učenci pogosto preučevale kot pomemben dejavnik medvrstniškega nasilja na ravni šole (npr. Khoury-Kassabri, Benbenishty, Astor in Zeira, 2004) in razreda (Di Stasio, Savage in Burgos, 2016) oziroma so preučevale pomen prepričanj učiteljev o medvrstniškem nasilju (KochenderferLadd in Pelletier, 2008) ali s strani učencev zaznanih odzivov učiteljev na medvrstniško nasilje (Saarento, Boulton in Salmivalli, 2015). Manj je raziskav, ki bi preučevale s strani učencev zaznano oporo učiteljev kot individualni dejavnik viktimizacije in nasilnega vedenja. Tako je na primer Cassidy (2009) ugotovil, da učenci z višjo stopnjo viktimizacije zaznavajo manj opore učiteljev, ni pa znano, kako svoj odnos $\mathrm{z}$ učitelji zaznavajo učenci z visoko stopnjo nasilnega vedenja. Namen pričujoče raziskave je tako med drugim zapolniti tudi to raziskovalno vrzel.

Naslednje odprto raziskovalno vprašanje, na katerega smo skušale poiskati odgovore, je vprašanje različnih nasproti deljenim napovednikom za različne oblike medvrstniškega nasilja. Večina raziskav namreč kljub uveljavljeni delitvi oblik medvrstniškega nasilja na telesno, besedno in odnosno nasilje pri opredeljevanju nasilja ne razločuje med posameznimi oblikami nasilja. Tako je malo znanega o morebitnih različnih in deljenih napovednikih posameznih oblik medvrstniškega nasilja in viktimizacije. Izjema je odnos med posameznimi oblikami medvrstniškega nasilja in spolom; raziskave (Nansel idr., 2001) so pokazale, da so fantje bodisi kot izvajalci bodisi kot žrtve nasilja pogosteje vključeni $\mathrm{v}$ neposredne oblike nasilja (telesno in besedno nasilje), medtem ko naj bi bila dekleta pogosteje vključena v odnosno nasilje kot bolj posredno obliko nasilja (Crick in Grotpeter, 1995), vendar pa raziskave v zvezi s slednjim ne omogočajo konsistentnih zaključkov (Salmivalli in Kaukiainen, 2004). Zaradi pomanjkanja raziskav o odnosu med posameznimi oblikami nasilja in različnimi psihosocialnimi izidi navajamo metaanalitično raziskavo Carda in sodelavcev (2008), ki se je osredotočala na medvrstniškemu nasilju soroden konstrukt agresivnosti; avtorji so poročali, da se neposredna (torej besedna in telesna) ter posredna (odnosna) agresivnost visoko povezujeta, pri čemer je povezanost za fante višja kot za dekleta. Kljub temu so avtorji poročali o ne povsem enakih vzorcih povezovanja posameznih oblik nasilja z različnimi psihosocialnimi izidi: neposredne oblike agresivnosti so se tako močneje povezovale s pozunanjanjem težav, neugodnimi vrstniškimi odnosi in nizko stopnjo prosocialnega vedenja, medtem ko se je odnosna agresivnost močneje povezovala $\mathrm{s}$ ponotranjanjem težav in se je pokazala kot manj negativno povezana s prosocialnim vedenjem. Spol in starost učencev $\mathrm{v}$ tej raziskavi nista predstavljala pomembnih moderatorjev omenjenih odnosov, medtem ko nekatere druge raziskave nakazujejo, da so napovedniki viktimizacije in nasilnega vedenja do neke mere spolno specifični. Tako naj bi bila na primer socialna sprejetost močnejši napovednik izvajanja nasilja pri fantih kot pri dekletih (Salmivalli, Lagerspetz, Björkqvist, Österman in Kaukiainen, 1996), zavrnjenost s strani vrstnikov pa se je pokazala kot močnejši napovednik viktimizacije pri dekletih (Bouman idr., 2012).
Izhajajoč iz obstoječih raziskovalnih ugotovitev o pomembni vlogi različnih vidikov socialnih odnosov za razumevanje viktimizacije in nasilnega vedenja učencev in upoštevajoč omenjena odprta raziskovalna vprašanja ter raziskovalne vrzeli je namen pričujoče raziskave preveriti vlogo vrstniških odnosov, operacionaliziranih tako kot samozaznana socialna opora (zaznana opora vrstnikov, socialna samopodoba) kakor tudi s strani vrstnikov zaznan položaj v skupini (s strani vrstnikov zaznana priljubljenost, prijateljski odnosi) pri napovedovanju telesne, besedne in odnosne viktimizacije in nasilja. Nadalje želimo preveriti, ali zaznana opora učiteljev pojasnjuje dodaten delež variance v merah vrstniške viktimizacije in nasilja. Prav tako želimo preveriti morebitno moderatorsko vlogo spola v odnosu med merami vrstniških odnosov in opore učiteljev ter različnimi oblikami medvrstniške viktimizacije in nasilja.

\section{Metoda}

\section{Udeleženci}

Ta raziskava je del večjega raziskovalnega projekta, katerega namen je bil preučiti varovalne dejavnike in dejavnike tveganja za medvrstniško nasilje pri učencih osnovnih šol (Košir idr., oddano v publikacijo). V raziskavi je sodelovalo 1905 učencev, od tega 950 fantov $(49,9 \%)$ in 955 deklet $(50,1 \%)$, starih med 11 in 16 let $(M=12,8 ; S D$ $=1,2)$. Vključenih je bilo 135 razredov iz 22 osnovnih šol v Sloveniji, v povprečju šest razredov na posamezno šolo. Izmed sodelujočih učencev jih je 422 (22,2\%) obiskovalo šesti razred, 482 (25,3\%) sedmi razred, 473 (24,8 \%) osmi razred in $528(27,7 \%)$ deveti razred.

\section{Pripomočki}

Vprašalnik medvrstniških odnosov: nasilno vedenje/viktimizacija (angl. Adolescent Peer Relations Instrument: Bully/Target; APRI-BT; Parada, 2000) je mera samoporočanega nasilnega vedenja in viktimizacije na telesni, besedni in odnosni ravni. Vprašalnik je sestavljen iz dveh delov, od katerih se prvi nanaša na nasilno vedenje, drugi pa na viktimizacijo. Vsak od teh delov zajema tri podlestvice, ki se nanašajo na telesno, besedno in odnosno nasilno vedenje in viktimizacijo. Vsaka podlestvica vsebuje 6 postavk, vsak del vprašalnika torej zajema po 18 postavk. Za podlestvico nasilno vedenje učenci s pomočjo 6-stopenjske lestvice pogostosti od 1 (nikoli) do 6 (vsak dan), označijo, kako pogosto so se $\mathrm{v}$ tem šolskem letu na opisan način vedli do sošolcev; $v$ delu, ki se nanaša na viktimizacijo, pa označijo, kako pogosto so se $v$ tem šolskem letu na opisan način sošolci vedli do njih. Primeri postavk za nasilno vedenje na telesni / besedni / odnosni ravni: „Sem potiskal/a učenca/učenko." / „Sem zafrkaval/a učence." / „Sem obrnil/a prijatelje proti učencu/učenki.« Primeri postavk za viktimizacijo na telesni / besedni / odnosni ravni: „So me učenci potiskali.« / „So se učenci norčevali iz mene. / / Je učenec/učenka obrnil/a svoje prijatelje proti meni.« 
Vprašalnik smo iz angleške verzije priredile za namen te raziskave. Opravile smo dva neodvisna prevoda iz angleškega $\mathrm{v}$ slovenski jezik, nato pa smo uskladile prevode ter oblikovale končno različico vprašalnika. Na našem vzorcu so se pokazali ustrezno visoki koeficienti za podlestvico nasilnega vedenja na telesni (Cronbachov $\alpha=0,82$ ), besedni (Cronbachov $\alpha=0,87$ ) in odnosni (Cronbachov $\alpha=0,72$ ) ravni. Marsh idr. (2011) poročajo o podobnih koeficientih notranje skladnosti (med 0,90 in 0,92). Koeficienti notranje skladnosti (Cronbachov $\alpha$ ) podlestvice viktimizacija za pričujoč vzorec znašajo 0,81 za telesno, 0,88 za besedno in 0,84 za odnosno viktimizacijo. Marsh idr. (2011) poročajo o koeficientih notranje skladnosti 0,92 za vse tri podlestvice ter o ustrezni konstruktni veljavnosti pripomočka. Na vseh postavkah vprašalnika smo v programu R (R Core Team, 2018) s paketom »lavaan« (Rosseel, 2012) izvedle konfirmatorno faktorsko analizo, s katero smo preverjale prileganje 6faktorskega modela podatkom. Za ocenjevanje parametrov modela smo uporabile robustno cenilko največjega verjetja (angl. maximum likelihood method, MLM), saj je bilo za porazdelitve postavk v splošnem značilno zmerno odstopanje od normalne porazdelitve. Ocenjevale smo tudi korelacije med latentnimi faktorji. Model se je dobro prilegal podatkom, $\chi^{2}(579)=1521,50 ;$ CFI $=0,94 ;$ TLI $=0,93$; RMSEA $=0,05$. Standardizirane nasičenosti so bile zadovoljive, in sicer: besedna viktimizacija: $M(\lambda)=0,75$; telesna viktimizacija: $M(\lambda)=0,65$; odnosna viktimizacija $M(\lambda)=0,69$; besedno nasilje: $M(\lambda)=0,74$; telesno nasilje: $M(\lambda)=0,66$; odnosno nasilje: $M(\lambda)=0,56$. Korelacije med latentnimi faktorji viktimizacije in nasilja so bile visoke (v razponu med 0,64 in 0,84 ) medtem ko so bile nekoliko nižje korelacije med latentnimi faktorji posameznih oblik nasilja in viktimizacije (v razponu med 0,20 in 0,52).

Tehnika vrstniških nominacij (npr. Perry, Kusel in Perry, 1988). S tehniko vrstniških nominacij smo merile priljubljenost in prijateljske odnose $\mathrm{v}$ razredu. Učenci so dobili navodilo, da ob postavkah »Je najbolj priljubljen/a $v$ razredu" in "Je tvoj dober prijatelj/dobra prijateljica" navedejo imena sošolk/sošolcev, za katere velja ta trditev. Učenci so lahko navedli do šest svojih sošolcev in sošolk. Spremenljivki priljubljenosti in prijateljskih odnosov sta bili izračunani za vsakega učenca posebej in standardizirani znotraj posameznega razreda $v$ obliki deleža glede na najvišje možno število nominacij v razredu udeleženca.

Lestvica zaznane opore (angl. Classroom Life Instrument; Johnson, Johnson in Anderson, 1983; slovenska priredba Košir in Pečjak, 2007) je sestavljena iz 12 dimenzij, ki sestavljajo razredno klimo. V naši raziskavi smo uporabile dimenzijo osebna opora s strani učiteljev, sestavljeno iz štirih postavk (primer postavk: »Mojim učiteljem ni vseeno zame.«) in dimenzijo osebna opora s strani vrstnikov, sestavljeno iz petih postavk (primer postavke: »Mojim sošolcem je pomembno, da so v prijateljskih odnosih z mano.«). Dimenziji merita stopnjo opore, ki jo učenci zaznavajo s strani učiteljev in sošolcev. Učenci na 5-stopenjski lestvici od 1 (nikoli ne drži) do 5 (vedno drži) označijo, kako pogosto se strinjajo z določeno trditvijo.

Koeficienti zanesljivosti za vprašalnik so $\mathrm{v}$ različnih raziskavah zadovoljivo visoki. Na naših podatkih znašata koeficienta notranje skladnosti Cronbachov $\alpha \quad 0,74$ za lestvico zaznane opore učiteljev in 0,85 za lestvico zaznane opore vrstnikov. Johnson idr. (1983) poročajo o ustreznih koeficientih notranje skladnosti $(0,78$ za oporo učiteljev in 0,80 za oporo vrstnikov). O enaki vrednosti koeficienta notranje skladnosti za slovensko priredbo lestvice zaznane opore vrstnikov poročata tudi Košir in Pečjak (2007), medtem ko je koeficient notranje skladnosti za lestvico zaznane opore učiteljev nekoliko nižji $(0,74)$. Košir in Tement (2014) poročata tudi o ustrezni faktorski strukturi slovenske priredbe obeh lestvic. Ustreznost prileganja dvo-faktorskega modela smo preverjale s konfirmatorno faktorsko analizo v programu R (R Core Team, 2018) s paketom »lavaan« (Rosseel, 2012) na vseh postavkah vprašalnika. Za ocenjevanje parametrov modela smo uporabile robustno cenilko največjega verjetja (MLM), saj je bilo za porazdelitve postavk v splošnem značilno zmerno odstopanje od normalne porazdelitve. Rezultati so pokazali ustrezno prileganje za dvo-faktorski model, $\chi^{2}(26)=181,78 ; \mathrm{CFI}=0,97$; TLI $=0,95$, RMSEA $=$ 0,06 . Standardizirane nasičenosti so bile zadovoljivo visoke za oporo učiteljev, $M(\lambda)=0,65$ in za oporo učencev $M(\lambda)=$ 0,72 . Korelacija med latentnima faktorjema je bila srednje visoka $(r=0,48)$.

Vprašalnik opisovanja samega sebe - SDQ II-S (angl. Self-Description Questionnaire II-S; Marsh, 1992) je multidimenzionalni vprašalnik za merjenje samopodobe mladostnikov. $\mathrm{V}$ naši raziskavi smo uporabile dimenzijo Odnosi z vrstniki, ki je sestavljena iz 10 postavk. Primer postavke je: »Težko sklepam prijateljstva." Udeleženci s pomočjo 5-stopenjske Likertove lestvice od 1 (ni tako) do 5 (tako je) odgovarjajo, v kolikšni meri se $\mathrm{z}$ dano trditvijo strinjajo. Koeficient notranje skladnosti Cronbachov $\alpha$ na naših podatkih znaša 0,86 , medtem ko Guérin, Marsh in Famose (2003) navajajo nekoliko višjo vrednost (Cronbachov $\alpha=0,94)$. Lennings in Lawer (1992) poleg dobre zanesljivosti poročata tudi o ustrezni napovedni veljavnosti Vprašalnika opisovanja samega sebe. Na našem vzorcu uporabljena podlestvica $\mathrm{V}$ pričakovani smeri korelira $\mathrm{z}$ drugimi konstrukti (tabela 1), kar kaže na ustrezno konstruktno veljavnost. Na vseh postavkah vprašalnika smo v programu R (R Core Team, 2018) s paketom »lavaan« (Rosseel, 2012) izvedle konfirmatorno faktorsko analizo, s katero smo preverjale prileganje enofaktorskega modela podatkom. Za ocenjevanje parametrov modela smo uporabile robustno cenilko največjega verjetja (MLM), saj je bilo za porazdelitve postavk v splošnem značilno zmerno odstopanje od normalne porazdelitve. Rezultati konfirmatorne faktorske analize so na naših podatkih pokazali slabo prileganje predpostavljenega enofaktorskega modela, $\chi^{2}(35)=559,55$; CFI $=0,87$; TLI $=$ 0,84 ; RMSEA $=0,11$. Po pregledu modifikacijskih indeksov, ki so pokazali, da bi boljše prileganje enofaktorskega modela lahko dosegli s koreliranjem treh parov napak postavk, smo model ponovno definirali s koreliranjem predlaganih treh parov postavk, ki so si vsebinsko zelo podobne (npr. » Z lahkoto sklepam prijateljstva $z$ vrstniki« in »Z lahkoto navezujem stike $z$ vrstniki«). Če bi se v prihodnjih validacijskih raziskavah te lestvice ponovno pokazalo, da so rezidualne variance teh postavk med seboj korelirane, predlagamo razmislek o odstranitvi ene od postavk iz vsakega para, ki ima slabše psihometrične značilnosti. Indikatorji prileganja za končni enofaktorski model so pokazali sprejemljivo prileganje 
podatkom, $\chi^{2}(32)=307,06 ; \mathrm{CFI}=0,94 ;$ TLI $=0,91$; RMSEA $=0,08 ; \Delta \chi^{2}(3)=214,05 ; p<0,001$. Standardizirane nasičenosti so bile zadovoljivo visoke, $M(\lambda)=0,60$.

\section{Postopek}

Pred pričetkom zbiranja podatkov smo pridobile soglasje šol za izvedbo raziskave. V zameno za sodelovanje so osnovnim šolam bile ponujene povratne informacije na skupinski ravni ter delavnice na temo preprečevanja nasilnega vedenja. Šolam, ki so se odločile za sodelovanje, smo nato razdelile informirana soglasja staršem otrok, ki so bili vključeni v raziskavo. Z namenom zagotavljanja večje zanesljivosti vrstniških nominacij so bili v vzorec vključeni le razredi, v katerih je sodelovalo vsaj 60 \% vseh učencev v razredu. Podoben kriterij je bil uporabljen tudi v drugih študijah vrstniških nominacij v razredu (npr. Košir, Horvat, Aram in Jurinec, 2016). Starše smo seznanile z namenom raziskave in $\mathrm{z}$ dejstvom, da reševanje vprašalnika ne bo popolnoma anonimno, saj se del vprašalnika nanaša na vrstniške nominacije, pri katerih morajo učenci pri določenih trditvah navesti imena svojih sošolcev ali svoje ime, v kolikor je navedena trditev značilna zanje. Imena so bila šifrirana pred analizo podatkov.

Učenci so vprašalnik reševali v razredu, v katerem je bila prisotna ena izmed članic raziskovalne skupine, ki je učencem pojasnila navodila in odgovorila na morebitna vprašanja, povezana $\mathrm{z}$ raziskavo. Učenci so $\mathrm{v}$ raziskavi sodelovali prostovoljno, za reševanje so potrebovali približno 40 minut. Raziskava je bila potrjena $\mathrm{s}$ strani Komisije za etičnost raziskovanja na Filozofski fakulteti Univerze v Mariboru.

\section{Rezultati}

Zbrani podatki predstavljajo primer večnivojske strukture, saj se deleži variance lahko nahajajo na ravni šole (III. raven), ravni razreda (II. raven) in na ravni posameznika (I. raven). Da bi naslovile ta problem in preverile, kolikšen delež variance se nahaja na posamezni ravni, smo uporabile večnivojsko modeliranje s pomočjo programa HLM 7 za OS Windows (Raudenbush, Bryk in Congdon, 2011). Ničelni trinivojski modeli (angl. intercept-only model) so bili testirani za vsako odvisno spremenljivko posebej. Vsi modeli so bili ocenjeni z metodo največjega verjetja (angl. full information maximum likelihood, FIML).

Potrebo po večnivojski obdelavi podatkov lahko preverimo preko relevantnosti oziroma deležev variance, ki se nahajajo na posamezni ravni (Peugh, 2010). V ta namen smo izračunale koeficient intraklasne korelacije (angl. intraclass correlation, ICC), ki nam pove pričakovano višino korelacije dveh naključno izbranih enot na odvisni spremenljivki v isti skupini (Hox, 2010). Intraklasna korelacija na ravni šole je bila za telesno viktimizacijo zelo nizka $\left(\mathrm{ICC}_{\text {šola }}=0,006\right)$. Nekoliko višja je bila na ravni razredov $\left(\mathrm{ICC}_{\text {razred }}=0,032\right)$. Podobne rezultate smo dobile za besedno viktimizacijo $\left(\mathrm{ICC}_{\text {šola }}<0,001 ; \mathrm{ICC}_{\text {razred }}=0,024\right)$ ter odnosno viktimizacijo $\left(\mathrm{ICC}_{\text {šola }}=0,012 ; \mathrm{ICC}_{\text {razred }}=0,013\right)$. Takšni rezultati nakazujejo, da je variabilnost posameznih skupin znotraj posameznih ravni (med 0 in 1,2\% na ravni šole ter med 1 in 3,2\% ravni razreda) nizka in zato ni potrebe po večnivojski hierarhični regresijski analizi.

Nekoliko višji so bili koeficienti intraklasne korelacije na vseh poddimenzijah nasilja. Koeficient intraklasne

Tabela 1. Opisne statistike in korelacije med obravnavanimi spremenljivkami

\begin{tabular}{|c|c|c|c|c|c|c|c|c|c|c|c|c|c|c|}
\hline & $M$ & $S D$ & 1. & 2. & 3. & 4. & 5. & 6. & 7. & 8. & 9. & 10. & 11. & 12. \\
\hline 1. Spol ${ }^{\mathrm{a}}$ & 0,50 & 1 & & & & & & & & & & & & \\
\hline 2. Starost & 12,80 & 1,20 &,$- 06^{* *}$ & & & & & & & & & & & \\
\hline \multicolumn{15}{|l|}{ Mere vrstniških odnosov } \\
\hline $\begin{array}{l}\text { 3. Zaznana opora } \\
\text { vrstnikov }\end{array}$ & 3,50 & 0,82 & 03 &,- 01 & & & & & & & & & & \\
\hline $\begin{array}{l}\text { 4. Socialna } \\
\text { samopodoba }\end{array}$ & 3,96 & 0,75 &,$- 05^{*}$ &, 02 &, $59^{* *}$ & & & & & & & & & \\
\hline 5. Priljubljenost & 11,82 & 16,51 &,- 03 &, 00 &, $15^{* *}$ &, $23^{* *}$ & & & & & & & & \\
\hline 6. Prijateljstvo & 21,67 & 13,29 &, 03 &,- 01 &, $24^{* *}$ &, $20^{* *}$ &, $42^{* *}$ & & & & & & & \\
\hline \multicolumn{15}{|l|}{ Opora učiteljev } \\
\hline $\begin{array}{l}\text { 7. Zaznana opora } \\
\text { učiteljev }\end{array}$ & 3,47 & 0,85 &, $08^{* *}$ &,$- 12^{* *}$ &, $39^{* *}$ &, $18^{* *}$ &,$- 06^{*}$ &, 00 & & & & & & \\
\hline \multicolumn{15}{|l|}{ Oblike viktimizacije } \\
\hline 8. Telesna viktimizacija & 1,43 & 0,63 &,$- 22^{* *}$ &,- 01 &,$- 25^{* *}$ &,$- 19^{* *}$ &, 00 &,$- 05^{*}$ &,$- 15^{* *}$ & & & & & \\
\hline $\begin{array}{l}\text { 9. Besedna } \\
\text { viktimizacija }\end{array}$ & 1,93 & 0,94 &,$- 08^{* *}$ &, 03 &,$- 41^{* *}$ &,$- 31^{* *}$ &,$- 08^{* *}$ &,$- 12^{* *}$ &,$- 15^{* *}$ &, $61^{* *}$ & & & & \\
\hline $\begin{array}{l}\text { 10. Odnosna } \\
\text { viktimizacija }\end{array}$ & 1,44 & 0,66 &, $05^{*}$ &,- 02 &,$- 39^{* *}$ &,$- 34^{* *}$ &,$- 10^{* *}$ &,$- 16^{* *}$ &,$- 13^{* *}$ &, $53^{* *}$ &, $69^{* *}$ & & & \\
\hline \multicolumn{15}{|l|}{ Oblike nasilja } \\
\hline 11. Telesno nasilje & 1,42 & 0,60 &,$- 32^{* *}$ &, $12^{* *}$ &,$- 08^{* *}$ &,- 03 &, $06^{*}$ &, 00 &,$- 22^{* *}$ &, $43^{* *}$ &, $25^{* *}$ &, $16^{* *}$ & & \\
\hline 12. Besedno nasilje & 1,86 & 0,83 &,$- 32^{* *}$ &, $12^{* *}$ &,$- 11^{* *}$ &,- 03 &, $09^{* *}$ &, 02 &,$- 26^{* *}$ &, $39^{* *}$ &, $35^{* *}$ &, $21^{* *}$ &, $72^{* *}$ & \\
\hline 13. Odnosno nasilje & 1,34 & 0,44 &,$- 14^{* *}$ &, $08^{* *}$ &,$- 05^{*}$ &,$- 08^{* *}$ &, 03 &,- 04 &,$- 14^{* *}$ &, $29^{* *}$ &, $29^{* *}$ &, $28^{* *}$ &, $57^{* *}$ &, $64^{* *}$ \\
\hline
\end{tabular}

Opombe. ${ }^{\text {a }}$ Spol: $0=$ moški, $1=$ ženski; ${ }^{*} p<0,05,{ }^{* *} p<0,001$. 
korelacije za telesno nasilje je bil nizek na ravni šole $\left(\mathrm{ICC}_{\text {šola }}=0,012\right)$, medtem ko je bil nekoliko višji na ravni razreda $\left(\mathrm{ICC}_{\text {razred }}=0,062\right)$. Podobni rezultati so se pokazali za besedno nasilje $\left(\mathrm{ICC}_{\text {šla }}=0,002 ; \mathrm{ICC}_{\text {razred }}=0,100\right)$ ter za odnosno nasilje $\left(\mathrm{ICC}_{\text {šola }}=0,007 ; \mathrm{ICC}_{\text {razred }}=0,059\right)$. Takšni rezultati kažejo, da lahko med 0,3 in 1,2 \% variabilnosti v poddimenzijah nasilja pripišemo razlikam med šolami ter med 6 in $10 \%$ variabilnosti razlikam med razredi. Raven šole je torej zanemarljiva, vrednosti koeficientov intraklasne korelacije za raven razreda nizke do srednje visoke glede na vrednosti, ki se običajno pojavljajo v večnivojskih analizah, značilnih v šolskem kontekstu. Glede na razmeroma nizke ICC koeficiente ter glavni namen članka, ki je bil preučiti individualne dejavnike nasilja na več dimenzijah nasilja in viktimizacije, smo za analizo podatkov uporabile hierarhično regresijsko analizo na individualni ravni.

Delež manjkajočih vrednosti na posamezni spremenljivki je bil nizek (pod 4 \% za vsako spremenljivko), vsak udeleženec je imel na vsaki lestvici vsaj $80 \%$ vrednosti. Manjkajoče vrednosti so bile nadomeščene $\mathrm{z}$ EM (angl. expectation maximization) algoritmom znotraj vsake dimenzije posebej. Opisne statistike vključenih spremenljivk so prikazane v tabeli 1. Pregled Pearsonovih koeficientov korelacij kaže, da fantje $\mathrm{z}$ izjemo odnosne viktimizacije na vseh odvisnih spremenljivkah dosegajo višje vrednosti $\mathrm{v}$ primerjavi $\mathrm{Z}$ dekleti. Starost je negativno povezana $\mathrm{z}$ zaznano oporo učiteljev in vsemi preučevanimi oblikami nasilja. Med seboj statistično značilno (nizko do zmerno visoko) korelirajo spremenljivke, združene pod merami vrstniških odnosov, t. j. zaznana opora vrstnikov, socialna samopodoba, priljubljenost in prijateljstvo. $Z$ zaznano oporo učiteljev v pozitivni smeri korelirata zaznana opora vrstnikov in socialna samopodoba, medtem ko je spremenljivka priljubljenost negativno, a nizko povezana z zaznano oporo učiteljev.

Po pričakovanjih med seboj pozitivno (zmerno do visoko) korelirajo vse oblike viktimizacije kot tudi vse oblike nasilnega vedenja. Zaznana opora učiteljev je negativno (nizko) povezana $\mathrm{z}$ vsemi preučevanimi oblikami viktimizacije in nasilja. $Z$ izjemo priljubljenosti so vse preučevane oblike viktimizacije statistično značilno negativno (nizko do zmerno visoko) povezane $\mathrm{z}$ merami vrstniških odnosov, medtem ko so korelacije mer vrstniških odnosov z nasiljem nižje in manj konsistentne. Vse korelacije so v pričakovani smeri, kar kaže na veljavnost merjenih konstruktov.

Tabela 2. Hierarhična multipla regresijska analiza za spremenljivke, ki napovedujejo telesno viktimizacijo

\begin{tabular}{|c|c|c|c|c|c|c|c|c|}
\hline & \multicolumn{8}{|c|}{ Telesna viktimizacija } \\
\hline & \multicolumn{2}{|c|}{ Model 1} & \multicolumn{2}{|c|}{ Model 2} & \multicolumn{2}{|c|}{ Model 3} & \multicolumn{2}{|c|}{ Model 4} \\
\hline & $B$ & $\beta$ & $B$ & $\beta$ & $B$ & $\beta$ & $B$ & $\beta$ \\
\hline \multicolumn{9}{|l|}{$\begin{array}{l}\text { Korak 1: Demografske } \\
\text { spremenljivke }\end{array}$} \\
\hline Spol $^{\mathrm{a}}$ & $-0,28$ &,$- 22^{* * *}$ & $-0,28$ &,$- 22^{* * *}$ & $-0,27$ &,$- 22^{* * *}$ & $-0,27$ &,$- 22^{* * *}$ \\
\hline Starost & $-0,01$ &,- 02 & $-0,01$ &,- 02 & $-0,01$ &,- 03 & $-0,01$ &,- 02 \\
\hline$R^{2}$ & & $05^{* * *}$ & & & & & & \\
\hline \multicolumn{9}{|l|}{$\begin{array}{l}\text { Korak 2: Mere vrstniških } \\
\text { odnosov }\end{array}$} \\
\hline Zaznana opora vrstnikov & & & $-0,15$ &,$- 19^{* * *}$ & $-0,13$ &,$- 17^{* * *}$ & $-0,20$ &,$- 27^{* * *}$ \\
\hline Socialna samopodoba & & & $-0,09$ &,$- 10^{* * *}$ & $-0,09$ &,$- 11^{* * *}$ & $-0,15$ &,$- 18^{* * *}$ \\
\hline Priljubljenost & & & 0,00 & 04 & 0,00 & 04 & 0,00 & 02 \\
\hline Prijateljstvo & & & 0,00 &, 01 & 0,00 & 00 & 0,00 & 01 \\
\hline$\Delta R^{2}$ & & & &, $07^{* * *}$ & & & & \\
\hline \multicolumn{9}{|l|}{$\begin{array}{l}\text { Korak 3: Zaznana opora } \\
\text { učiteljev }\end{array}$} \\
\hline Zaznana opora učiteljev & & & & & $-0,03$ &,- 04 & $-0,03$ &,- 04 \\
\hline$\Delta R^{2}$ & & & & & &, 00 & & \\
\hline \multicolumn{9}{|l|}{ Korak 4: Interakcija } \\
\hline $\begin{array}{l}\text { Spol x zaznana opora } \\
\text { vrstnikov }\end{array}$ & & & & & & & 0,14 &, $13^{* *}$ \\
\hline $\begin{array}{l}\text { Spol x socialna samopo- } \\
\text { doba }\end{array}$ & & & & & & & 0,10 &, $09^{*}$ \\
\hline Spol x priljubljenost & & & & & & & 0,00 &, 03 \\
\hline Spol x prijateljstvo & & & & & & & 0,00 &,- 01 \\
\hline $\begin{array}{l}\text { Spol x zaznana opora } \\
\text { učiteljev }\end{array}$ & & & & & & & 0,00 &, 00 \\
\hline$\Delta R^{2}$ & & & & & & & &, $02^{* * *}$ \\
\hline$R^{2}$ & & $5^{* * *}$ & & & & $2^{* * *}$ & & \\
\hline$F$ za spremembo $R^{2}$ & & $8^{* * *}$ & & & & & & \\
\hline
\end{tabular}

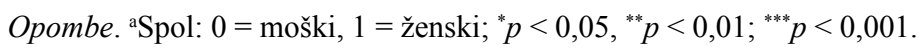




\section{Napovedniki različnih oblik viktimizacije in nasilja}

Da bi določile napovedno vrednost demografskih spremenljivk, mer vrstniških odnosov in opore učitelja za različne oblike viktimizacije in nasilja, smo uporabile hierarhično moderirano regresijsko analizo $\mathrm{z}$ metodo vključitve (angl. enter). Vsi napovedniki so bili centrirani okoli povprečja v izogib multikolinearnosti (Aiken in West, 1991). Preliminarne analize so pokazale, da so izpolnjene vse predpostavke za hierarhično regresijo. Na podlagi indikatorjev VIF (angl. variance inflation factor) lahko sklenemo, da v naših podatkih ni problemov z multikolinearnostjo (VIF indikatorji so med 1 in 2). Preverile smo še obstoj vplivnih točk, ki bi lahko popačile regresijski model, ki pa jih v naših analizah ni zaznati (vrednosti Cookove razdalje so bile med 0,03 in 0,09). Nadaljnji pregled predpostavk je pokazal, da za izbrane modele bistveno ne kršimo predpostavk homoskedastičnosti, linearnosti in približno normalne porazdelitve rezidualov (standardizirani koeficienti so bili med -2,25 in 8,27).
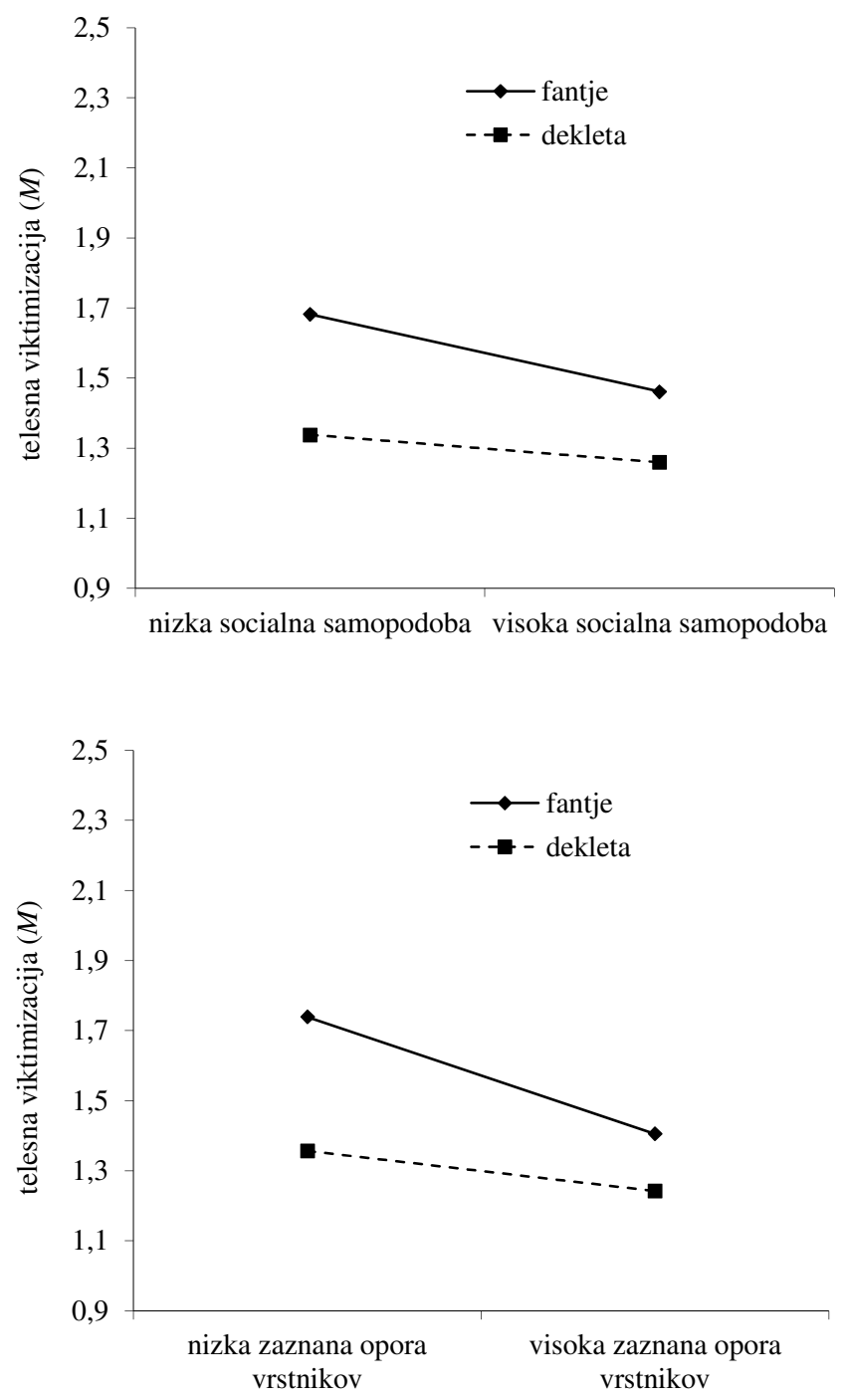

Slika 1. Spol kot moderator odnosa med zaznano oporo vrstnikov in telesno viktimizacijo (zgoraj) in socialno samopodobo in telesno viktimizacijo (spodaj).
Pri vseh odvisnih spremenljivkah smo v model najprej vključile demografske spremenljivke (spol in starost), nato v drugem koraku mere vrstniških odnosov (zaznana opora vrstnikov, socialna samopodoba, priljubljenost, prijateljstvo), zatem pa zaznano oporo učiteljev. V zadnjem, četrtem koraku smo vključile interakcije s spolom, saj nas je zanimalo, ali je spol moderator odnosa med merami vrstniških odnosov in zaznano oporo učiteljev ter različnimi oblikami medvrstniške viktimizacije in nasilja.

Viktimizacija. Kot je prikazano v tabelah 2, 3 in 4, je $\mathrm{z}$ demografskimi spremenljivkami, vključenimi $\mathrm{v}$ prvem koraku, mogoče pojasniti $1 \%$ variance $\mathrm{v}$ besedni in 5 $\%$ variance $v$ telesni viktimizaciji. Izmed demografskih spremenljivk je zgolj spol pomemben napovednik vseh preučevanih oblik viktimizacije. Nakazana smer povezanosti spola je za besedno in telesno viktimizacijo negativna, za odnosno viktimizacijo pa pozitivna, kar pomeni, da fantje poročajo o višji stopnji telesne in besedne viktimizacije, dekleta pa o višji stopnji odnosne viktimizacije.
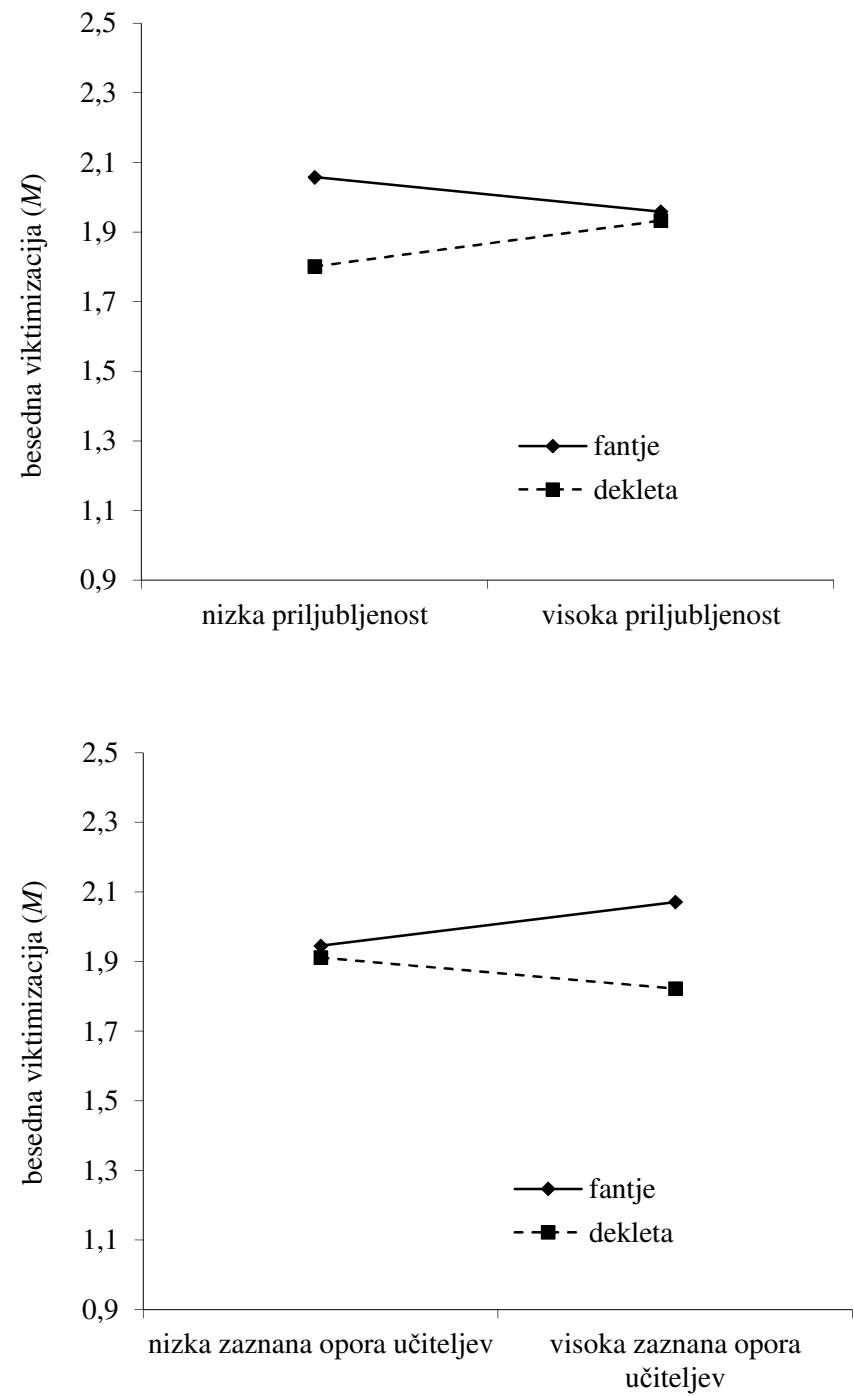

Slika 2. Spol kot moderator odnosa med priljubljenostjo in besedno viktimizacijo (zgoraj) in med zaznano oporo učiteljev in besedno viktimizacijo (spodaj). 
Vključitev mer vrstniških odnosov dodatno pojasni $17 \%$ besedne, $7 \%$ telesne in $18 \%$ odnosne viktimizacije. Zaznana opora vrstnikov in socialna samopodoba negativno napovedujeta vse preučevane oblike viktimizacije; učenci z višjo zaznano oporo vrstnikov in višjo socialno samopodobo poročajo o manjši meri viktimizacije. Vključitev zaznane opore učiteljev $\mathrm{v}$ tretjem koraku dodatno pojasni majhen delež variance zgolj v besedni viktimizaciji.

$\mathrm{V}$ četrtem koraku smo dodale interakcijske učinke mer vrstniških odnosov in zaznane opore učiteljev s spolom, ki statistično značilno dodatno pojasnijo $1 \%$ variance $\mathrm{v}$ besedni ter $2 \%$ variance $\mathrm{v}$ telesni viktimizaciji, dodatno pa ne pojasnijo variabilnosti $\mathrm{v}$ odnosni viktimizaciji. Kot prikazujemo v tabeli 2, sta zaznana opora vrstnikov in socialna samopodoba negativno povezani s telesno viktimizacijo in spol statistično značilno moderira ta odnos. Obe interakciji sta prikazani na sliki 1 . Fantje, ki so poročali o visoki opori vrstnikov, so poročali o nižji stopnji telesne viktimizacije (analiza enostavnih naklonov za fante, $p<0,001$ ), podoben učinek, vendar v manjši meri, se je pokazal za dekleta ( $p=$ $0,023)$. Socialna samopodoba za dekleta ni bila pomembno povezana s telesno viktimizacijo $(p=0,322)$, za fante pa je visoka samopodoba napovedovala nižjo telesno viktimizacijo $(p<0,001)$.

Iz tabele 3 je razvidno, da je spol statistično značilen moderator odnosa med $\mathrm{s}$ strani vrstnikov zaznano priljubljenostjo in zaznano oporo učitelja ter besedno viktimizacijo. Obe interakciji sta prikazani na sliki 2. Dekleta, ki so manj priljubljena, doživljajo manj besedne viktimizacije $(p=0,046)$, medtem ko za fante priljubljenost nima učinka na besedno viktimizacijo ( $p=0,083)$. Zaznana opora učitelja ima pomembno vlogo samo pri fantih; fantje, ki zaznavajo visoko oporo učiteljev, poročajo o višji besedni viktimizaciji $(p=0,019)$, pri dekletih zaznana opora učiteljev ni povezana $\mathrm{z}$ besedno viktimizacijo ( $p=0,236)$.

Nasilje. Rezultati hierarhične multiple regresijske analize so pokazali, da nekatere demografske spremenljivke kot tudi posamezne mere vrstniških odnosov in zaznana opora učiteljev, napovedujejo besedno, telesno in odnosno nasilje.

$\mathrm{V}$ prvem koraku smo vnesle demografski spremenljivki spol in starost, pri čemer je iz rezultatov $v$ tabelah 5,6 in 7 razvidno, da je mogoče $z$ demografskimi spremenljivkami pojasniti po $11 \%$ variance $\mathrm{v}$ besednem in telesnem nasilju ter $3 \%$ variance pri odnosnem nasilju. Demografski

Tabela 3. Hierarhična multipla regresijska analiza za spremenljivke, ki napovedujejo besedno viktimizacijo

\begin{tabular}{|c|c|c|c|c|c|c|c|c|}
\hline & \multicolumn{8}{|c|}{ Besedna viktimizacija } \\
\hline & \multicolumn{2}{|c|}{ Model 1} & \multicolumn{2}{|c|}{ Model 2} & \multicolumn{2}{|c|}{ Model 3} & \multicolumn{2}{|c|}{ Model 4} \\
\hline & $B$ & $\beta$ & $B$ & $\beta$ & $B$ & $\beta$ & $B$ & $\beta$ \\
\hline \multicolumn{9}{|l|}{$\begin{array}{l}\text { Korak 1: Demografske } \\
\text { spremenljivke }\end{array}$} \\
\hline $\mathrm{Spol}^{\mathrm{a}}$ & $-0,15$ &,$- 08^{* * *}$ & $-0,14$ &,$- 08^{* * *}$ & $-0,14$ &,$- 08^{* * *}$ & $-0,14$ &,$- 08^{* * *}$ \\
\hline Starost & 0,02 & ,02 & 0,02 & ,02 & 0,02 & ,02 & 0,02 & 03 \\
\hline$R^{2}$ & &, $01^{*}$ & & & & & & \\
\hline \multicolumn{9}{|l|}{$\begin{array}{l}\text { Korak 2: Mere vrstniških } \\
\text { odnosov }\end{array}$} \\
\hline $\begin{array}{l}\text { Zaznana opora } \\
\text { vrstnikov }\end{array}$ & & & $-0,38$ &,$- 33^{* * *}$ & $-0,38$ &,$- 33^{* * *}$ & $-0,42$ &,$- 37^{* * *}$ \\
\hline Socialna samopodoba & & & $-0,15$ &,$- 12^{* * *}$ & $-0,15$ &,$- 12^{* * *}$ & $-0,21$ &,$- 16^{* * *}$ \\
\hline Priljubljenost & & & 0,00 &, 01 & 0,00 &, 01 & 0,00 &,- 05 \\
\hline Prijateljstvo & & & 0,00 &,- 02 & 0,00 &,- 02 & 0,00 &,- 01 \\
\hline$\Delta R^{2}$ & & & &, $17^{* * *}$ & & & & \\
\hline \multicolumn{9}{|l|}{$\begin{array}{l}\text { Korak 3: Zaznana opora } \\
\text { učiteljev }\end{array}$} \\
\hline Zaznana opora učiteljev & & & & & 0,02 &, 01 & 0,08 &, $07^{*}$ \\
\hline$\Delta R^{2}$ & & & & & &, 00 & & \\
\hline \multicolumn{9}{|l|}{ Korak 4: Interakcija } \\
\hline $\begin{array}{l}\text { Spol x zaznana opora } \\
\text { vrstnikov }\end{array}$ & & & & & & & 0,07 & 05 \\
\hline $\begin{array}{l}\text { Spol x socialna } \\
\text { samopodoba }\end{array}$ & & & & & & & 0,09 & 05 \\
\hline Spol x priljubljenost & & & & & & & 0,01 &, $08^{*}$ \\
\hline Spol x prijateljstvo & & & & & & & 0,00 &,- 02 \\
\hline $\begin{array}{l}\text { Spol x zaznana opora } \\
\text { učiteljev }\end{array}$ & & & & & & & $-0,13$ &,$- 08^{* *}$ \\
\hline$\Delta R^{2}$ & & & & & & & &, $01^{*}$ \\
\hline$R^{2}$ & \multicolumn{2}{|c|}{, $01^{* *}$} & \multicolumn{2}{|c|}{, $18^{* * *}$} & \multicolumn{2}{|c|}{, $18^{* * *}$} & \multicolumn{2}{|c|}{, $19^{* * *}$} \\
\hline$F$ za spremembo $R^{2}$ & \multicolumn{2}{|c|}{$6,81^{* *}$} & \multicolumn{2}{|c|}{$99,25^{* * *}$} & \multicolumn{2}{|c|}{0,34} & \multicolumn{2}{|c|}{$4,12^{* *}$} \\
\hline
\end{tabular}

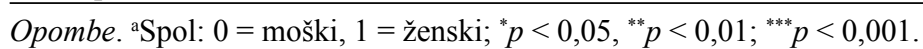


Tabela 4. Hierarhična multipla regresijska analiza za spremenljivke, ki napovedujejo odnosno viktimizacijo

\begin{tabular}{|c|c|c|c|c|c|c|c|c|}
\hline & \multicolumn{8}{|c|}{ Odnosna viktimizacija } \\
\hline & \multicolumn{2}{|c|}{ Model 1} & \multicolumn{2}{|c|}{ Model 2} & \multicolumn{2}{|c|}{ Model 3} & \multicolumn{2}{|c|}{ Model 4} \\
\hline & $B$ & $\beta$ & $B$ & $\beta$ & $B$ & $\beta$ & $B$ & $\beta$ \\
\hline \multicolumn{9}{|l|}{$\begin{array}{l}\text { Korak 1: Demografske } \\
\text { spremenljivke }\end{array}$} \\
\hline $\mathrm{Spol}^{\mathrm{a}}$ & 0,06 &, $05^{*}$ & 0,06 &, $05^{*}$ & 0,06 &, $05^{*}$ & 0,06 &, $05^{*}$ \\
\hline Starost & $-0,01$ &,- 02 & $-0,01$ &,- 02 & $-0,01$ &,- 02 & $-0,01$ &,- 01 \\
\hline$\Delta R^{2}$ & &, 00 & & & & & & \\
\hline \multicolumn{9}{|l|}{$\begin{array}{l}\text { Korak 2: Mere } \\
\text { vrstniških odnosov }\end{array}$} \\
\hline $\begin{array}{l}\text { Zaznana opora } \\
\text { vrstnikov }\end{array}$ & & & $-0,23$ &,$- 29^{* * *}$ & $-0,23$ &,$- 29^{* * *}$ & $-0,26$ &,$- 32^{* * *}$ \\
\hline Socialna samopodoba & & & $-0,14$ &,$- 16^{* * *}$ & $-0,14$ &,$- 16^{* * *}$ & $-0,16$ &,$- 18^{* * *}$ \\
\hline Priljubljenost & & & 0,00 &, 01 & 0,00 &, 01 & 0,00 &,- 02 \\
\hline Prijateljstvo & & & 0,00 &,$- 06^{* *}$ & 0,00 &,$- 06^{* *}$ & 0,00 &,$- 05^{* *}$ \\
\hline$\Delta R^{2}$ & & & &, $18^{* * *}$ & & & & \\
\hline \multicolumn{9}{|l|}{$\begin{array}{l}\text { Korak 3: Zaznana } \\
\text { opora učiteljev }\end{array}$} \\
\hline $\begin{array}{l}\text { Zaznana opora } \\
\text { učiteljev }\end{array}$ & & & & & 0,00 &, 00 & 0,03 &, 04 \\
\hline$\Delta R^{2}$ & & & & & &, 00 & & \\
\hline \multicolumn{9}{|l|}{ Korak 4: Interakcija } \\
\hline $\begin{array}{l}\text { Spol x zaznana opora } \\
\text { vrstnikov }\end{array}$ & & & & & & & 0,05 &, 05 \\
\hline $\begin{array}{l}\text { Spol x socialna } \\
\text { samopodoba }\end{array}$ & & & & & & & 0,04 &, 03 \\
\hline Spol x priljubljenost & & & & & & & 0,00 &, 05 \\
\hline Spol x prijateljstvo & & & & & & & 0,00 &,- 02 \\
\hline $\begin{array}{l}\text { Spol x zaznana opora } \\
\text { učiteljev }\end{array}$ & & & & & & & $-0,05$ &,- 05 \\
\hline$\Delta R^{2}$ & & & & & & & &, 00 \\
\hline$R^{2}$ & \multicolumn{2}{|c|}{, 00} & \multicolumn{2}{|c|}{, $18^{* * *}$} & \multicolumn{2}{|c|}{, $18^{* * *}$} & \multicolumn{2}{|c|}{, $18^{* * *}$} \\
\hline$F$ za spremembo $R^{2}$ & \multicolumn{2}{|c|}{2,37} & \multicolumn{2}{|c|}{$101,17^{* * *}$} & \multicolumn{2}{|c|}{0,04} & \multicolumn{2}{|c|}{1,86} \\
\hline
\end{tabular}

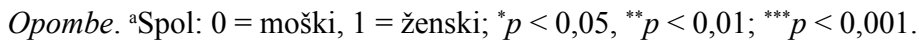
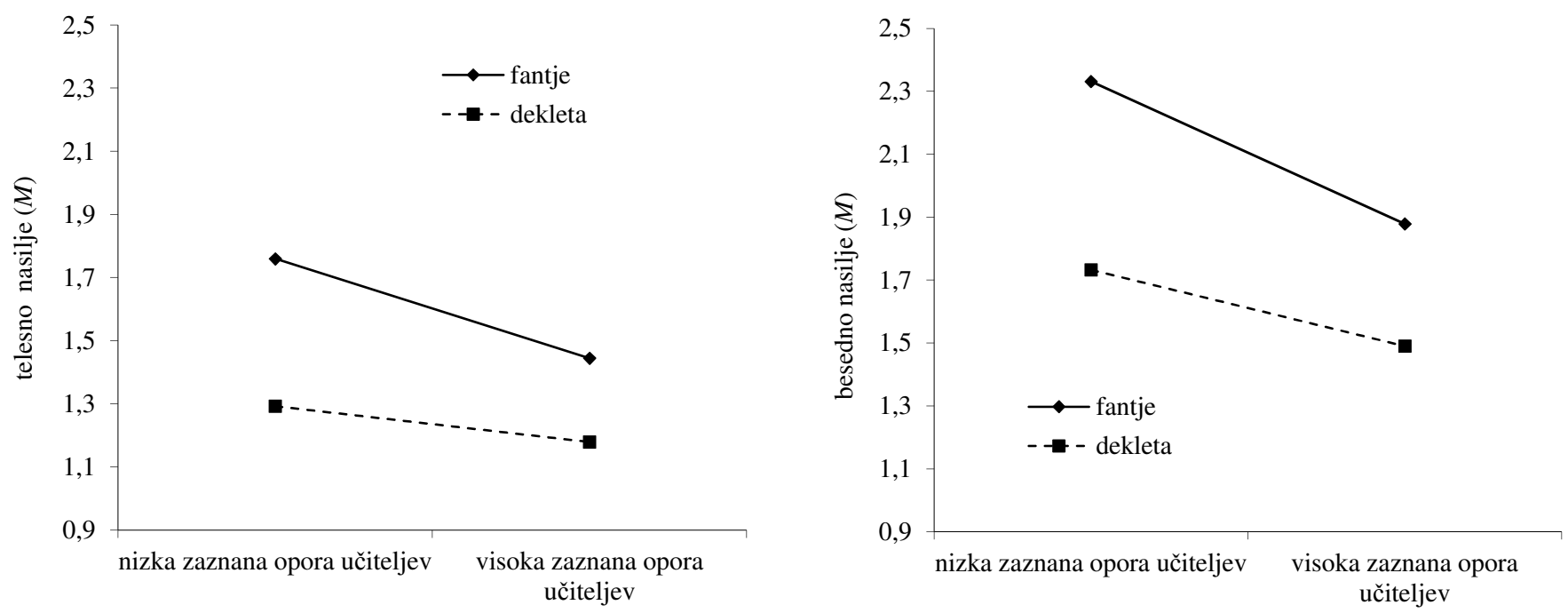

Slika 3. Spol kot moderator odnosa med zaznano oporo učiteljev in telesnim (levo) in besednim nasiljem (desno). 
Tabela 5. Hierarhična multipla regresijska analiza za spremenljivke, ki napovedujejo telesno nasilje

\begin{tabular}{|c|c|c|c|c|c|c|c|c|}
\hline & \multicolumn{8}{|c|}{ Telesno nasilje } \\
\hline & \multicolumn{2}{|c|}{ Model 1} & \multicolumn{2}{|c|}{ Model 2} & \multicolumn{2}{|c|}{ Model 3} & \multicolumn{2}{|c|}{ Model 4} \\
\hline & $B$ & $\beta$ & $B$ & $\beta$ & $B$ & $\beta$ & $B$ & $\beta$ \\
\hline \multicolumn{9}{|l|}{$\begin{array}{l}\text { Korak 1: Demografske } \\
\text { spremenljivke }\end{array}$} \\
\hline $\mathrm{Spol}^{\mathrm{a}}$ & $-0,38$ &,$- 32^{* * *}$ & $-0,38$ &,$- 31^{* * *}$ & $-0,37$ &,$- 30^{* * *}$ & $-0,37$ &,$- 30^{* * *}$ \\
\hline Starost & 0,05 &, $10^{* * *}$ & 0,05 &, $10^{* * *}$ & 0,04 &, $08^{* * *}$ & 0,04 &, $08^{* * *}$ \\
\hline$\Delta R^{2}$ & &, $11^{* * *}$ & & & & & & \\
\hline \multicolumn{9}{|l|}{$\begin{array}{l}\text { Korak 2: Mere } \\
\text { vrstniških odnosov }\end{array}$} \\
\hline $\begin{array}{l}\text { Zaznana opora } \\
\text { vrstnikov }\end{array}$ & & & $-0,05$ &,$- 07^{* *}$ & 0,01 & 01 & $-0,02$ &,- 02 \\
\hline Socialna samopodoba & & & $-0,02$ &,- 02 & $-0,03$ &,- 03 & $-0,04$ &,- 05 \\
\hline Priljubljenost & & & 0,00 &, $06^{*}$ & 0,00 &, 04 & 0,00 &, $08^{*}$ \\
\hline Prijateljstvo & & & 0,00 & 01 & 0,00 &, 00 & 0,00 &, 02 \\
\hline$\Delta R^{2}$ & & & &, $01^{* *}$ & & & & \\
\hline \multicolumn{9}{|l|}{$\begin{array}{l}\text { Korak 3: Zaznana opora } \\
\text { učiteljev }\end{array}$} \\
\hline $\begin{array}{l}\text { Zaznana opora } \\
\text { učiteljev }\end{array}$ & & & & & $-0,13$ &,$- 19^{* * *}$ & $-0,19$ &,$- 26^{* * *}$ \\
\hline$\Delta R^{2}$ & & & & & &, $03^{* * *}$ & & \\
\hline \multicolumn{9}{|l|}{ Korak 4: Interakcija } \\
\hline $\begin{array}{l}\text { Spol x zaznana opora } \\
\text { vrstnikov }\end{array}$ & & & & & & & 0,04 & ,04 \\
\hline $\begin{array}{l}\text { Spol x socialna } \\
\text { samopodoba }\end{array}$ & & & & & & & 0,02 & ,02 \\
\hline Spol x priljubljenost & & & & & & & 0,00 &,- 06 \\
\hline Spol x prijateljstvo & & & & & & & 0,00 &,- 02 \\
\hline $\begin{array}{l}\text { Spol x zaznana opora } \\
\text { učiteljev }\end{array}$ & & & & & & & 0,12 &, $11^{* * *}$ \\
\hline$\Delta R^{2}$ & & & & & & & &, $01^{* * *}$ \\
\hline$R^{2}$ & & $11^{* * *}$ & & & & $5^{* * *}$ & & $6^{* * *}$ \\
\hline$F$ za spremembo $R^{2}$ & & $5^{* * *}$ & & & & & & $8^{* * *}$ \\
\hline
\end{tabular}

Opombe. ${ }^{\text {aSpol: } 0} 0$ moški, 1 = ženski; ${ }^{*} p<0,05,{ }^{* *} p<0,01 ;{ }^{* * *} p<0,001$.

spremenljivki spol in starost sta se izkazali kot pomembna napovednika vseh preučevanih oblik nasilja. Fantje so pri vseh preučevanih oblikah o nasilju poročali v večji meri kot dekleta, starejši učenci pa so o nasilju poročali v večji meri kot mlajši.

Mere vrstniških odnosov, ki so bile dodane $\mathrm{v}$ drugem koraku, skupaj pojasnijo statistično značilen dodaten delež variance. Pri besednem nasilju dodatno pojasnijo $2 \%$ celotne variance, pritelesneminodnosnemnasiljupadodatnopojasnijo $1 \%$ celotne variance. Pregled standardiziranih regresijskih uteži na merah vrstniških odnosov v končnem modelu kaže, da je zaznana opora vrstnikov statistično značilen napovednik odnosnega nasilja, kar pomeni, da učenec, ki zaznava višjo stopnjo opore s strani vrstnikov, izvaja več odnosnega nasilja. Socialna samopodoba in prijateljski odnosi predstavljajo statistično značilna napovednika odnosnega nasilja, pri čemer je smer povezanosti negativna, kar pomeni, da učenci $\mathrm{z}$ višjo samopodobo in $\mathrm{z}$ višjo stopnjo prijateljstev $\mathrm{v}$ manjši meri izvajajo odnosno nasilje. S strani vrstnikov zaznana priljubljenost pozitivno napoveduje vse preučevane oblike nasilja: učenci, ki so zaznani kot bolj priljubljeni, v večji meri poročajo o izvajanju besednega, telesnega in odnosnega nasilja.

$\mathrm{V}$ tretjem koraku je bila dodana spremenljivka zaznana opora učiteljev, ki dodatno pojasnjuje $4 \%$ variance $\mathrm{v}$ besednem, $3 \% \mathrm{v}$ telesnem in $2 \%$ variance $\mathrm{v}$ odnosnem nasilju. Zaznana opora učiteljev predstavlja negativen napovednik vseh treh oblik nasilja: učenci, ki zaznavajo manj opore učiteljev, poročajo o več izvajanja telesnega, besednega in odnosnega nasilja.

Vključitev spola kot moderatorja med psihosocialnimi značilnostmi in preučevanimi oblikami nasilja $\mathrm{v}$ četrtem koraku dodatno pojasnjuje $1 \%$ variance $\mathrm{v}$ besednem in telesnem nasilju. $\mathrm{V}$ odnosnem nasilju spol ni moderiral nobenega izmed vključenih napovednikov. Spol se kaže kot statistično značilen moderator odnosa med zaznano oporo učiteljev in telesnim in besednim nasiljem. Obe interakciji sta prikazani na sliki 3. Analiza enostavnih naklonov je pokazala, da fantje, ki zaznavajo več opore učiteljev, poročajo o izvajanju manj besednega $(p<0,001)$ in telesnega nasilja ( $p$ $<0,001$ ), pri dekletih pa zaznana opora učiteljev ne predstavlja pomembnega napovednika telesnega nasilja, je pa pomemben dejavnik pri besednem nasilju $(p<0,001)$. 
Tabela 6. Hierarhična multipla regresijska analiza za spremenljivke, ki napovedujejo besedno nasilje

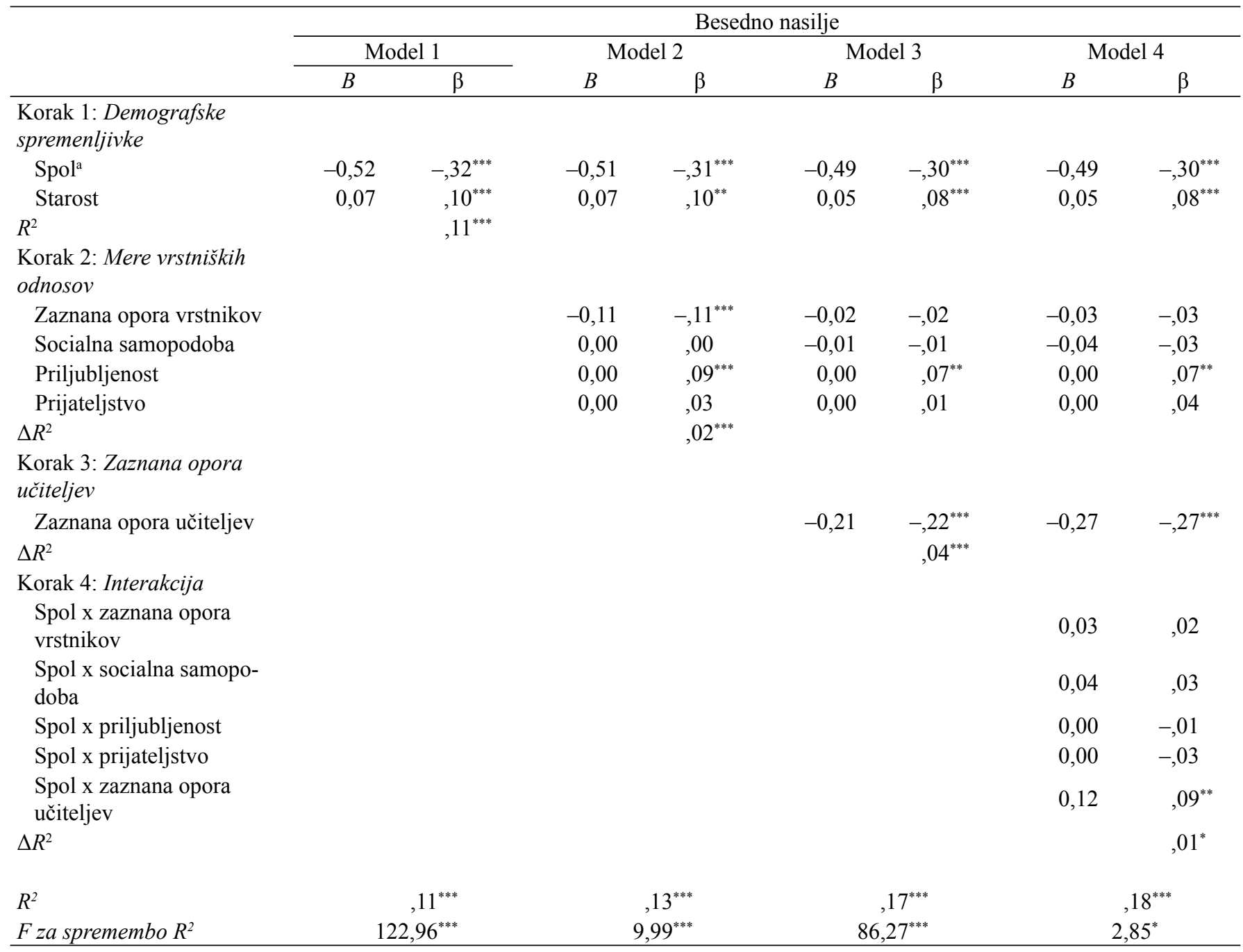

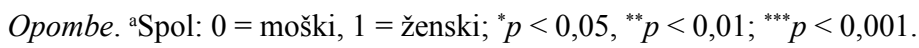

\section{Razprava}

Namen raziskave je bil preveriti nekatere psihosocialne značilnosti učencev kot napovednike stopnje telesne, besedne in odnosne viktimizacije ter izvajanja telesnega, besednega in odnosnega nasilja v vrstniških odnosih. Pri tem so nas zanimali vzorci odnosov med različnimi pokazatelji učenčevega psihosocialnega delovanja (zaznana opora vrstnikov, socialna samopodoba, s strani vrstnikov zaznana priljubljenost in prijateljski odnosi, zaznana opora učiteljev) in različnimi oblikami viktimizacije in nasilnega vedenja $v$ vrstniških odnosih. Še posebej nas je zanimala morebitna napovedna vrednost zaznane učiteljeve opore oziroma morebiten dodatni delež pojasnjene variance $\mathrm{v}$ različnih oblikah viktimizacije in nasilnega vedenja, ki ga ni mogoče pojasniti z merami vrstniških odnosov. Prav tako smo preverile, ali predstavlja spol moderator odnosa med psihosocialnimi značilnostmi učencev in različnimi oblikami medvrstniške viktimizacije in nasilnega vedenja - torej ali se odnos med psihosocialnimi značilnostmi in samoporočano viktimizacijo ter nasiljem med dekleti in fanti razlikuje. $\mathrm{V}$ razpravi pojasnjujemo odnose med posameznimi oblikami viktimizacije oziroma nasilnega vedenja, nato pa se osredotočamo na napovednike posameznih oblik medvrstniške viktimizacije in nasilja ter deleže variance, ki ga pojasnijo posamezni sklopi napovednikov. Iz teh ugotovitev izpeljemo nekaj smernic za nadaljnje raziskovanje in za psihološko oziroma šolsko prakso.

Pregled korelacij med posameznimi oblikamiviktimizacije ter med posameznimi oblikami nasilja kaže na zmerno do visoko povezanost med posameznimi poddimenzijami znotraj konstruktov viktimizacije in nasilja, kar nakazuje na precejšnje, a nikakor ne popolno prekrivanje med konstrukti. Stopnja povezanosti med posameznimi dimenzijami viktimizacije in posameznimi oblikami nasilja je pozitivna ter nizka oziroma zmerna. Učenci, ki poročajo o višji stopnji doživljanja posameznih oblik nasilja, tako poročajo tudi o več nasilnega vedenja na vseh treh področjih. Kljub temu navedeni vzorci povezanosti kažejo na relativno neodvisnost pojavov viktimizacije in nasilnega vedenja in potrjujejo ustreznost dvodimenzionalnega pojmovanja viktimizacije in nasilnega vedenja (Sanders in Phye, 2004).

Spol se je izkazal kot pomemben napovednik vseh treh pojavnih oblik tako viktimizacije kot nasilnega vedenja; fantje so poročali o višji stopnji telesne in besedne viktimizacije ter o višji stopnji telesnega, besednega in odnosnega nasilja, 
Tabela 7. Hierarhična multipla regresijska analiza za spremenljivke, ki napovedujejo odnosno nasilje

\begin{tabular}{|c|c|c|c|c|c|c|c|c|}
\hline & \multicolumn{8}{|c|}{ Odnosno nasilje } \\
\hline & \multicolumn{2}{|c|}{ Model 1} & \multicolumn{2}{|c|}{ Model 2} & \multicolumn{2}{|c|}{ Model 3} & \multicolumn{2}{|c|}{ Model 4} \\
\hline & $B$ & $\beta$ & $B$ & $\beta$ & $B$ & $\beta$ & $B$ & $\beta$ \\
\hline \multicolumn{9}{|l|}{$\begin{array}{l}\text { Korak 1: Demografske } \\
\text { spremenljivke }\end{array}$} \\
\hline Spol $^{\mathrm{a}}$ & $-0,12$ &,$- 14^{* * *}$ & $-0,13$ &,$- 14^{* * *}$ & $-0,12$ &,$- 14^{* * *}$ & $-0,12$ &,$- 14^{* * *}$ \\
\hline Starost & 0,03 &, $08^{* *}$ & 0,03 &, $08^{* *}$ & 0,02 &, $06^{* *}$ & 0,02 &, $06^{* *}$ \\
\hline$R^{2}$ & &, $03^{* * *}$ & & & & & & \\
\hline \multicolumn{9}{|l|}{$\begin{array}{l}\text { Korak 2: Mere } \\
\text { vrstniških odnosov }\end{array}$} \\
\hline $\begin{array}{l}\text { Zaznana opora } \\
\text { vrstnikov }\end{array}$ & & & 0,01 &, 03 & 0,05 &, $09^{* *}$ & 0,05 &, $09^{*}$ \\
\hline Socialna samopodoba & & & $-0,07$ &,$- 11^{* * *}$ & $-0,07$ &,$- 12^{* * *}$ & $-0,08$ &,$- 14^{* *}$ \\
\hline Priljubljenost & & & 0,00 &, $06^{* *}$ & 0,00 &, $05^{*}$ & 0,00 &, $07^{*}$ \\
\hline Prijateljstvo & & & 0,00 &,- 04 & 0,00 &,$- 05^{*}$ & 0,00 &,$- 05^{*}$ \\
\hline$\Delta R^{2}$ & & & &, $01^{* * *}$ & & & & \\
\hline \multicolumn{9}{|l|}{$\begin{array}{l}\text { Korak 3: Zaznana } \\
\text { opora učiteljev }\end{array}$} \\
\hline $\begin{array}{l}\text { Zaznana opora } \\
\text { učiteljev }\end{array}$ & & & & & $-0,07$ &,$- 13^{* * *}$ & $-0,07$ &,$- 15^{* * *}$ \\
\hline$\Delta R^{2}$ & & & & & &, $02^{* * *}$ & & \\
\hline \multicolumn{9}{|l|}{ Korak 4: Interakcija } \\
\hline $\begin{array}{l}\text { Spol x zaznana opora } \\
\text { vrstnikov }\end{array}$ & & & & & & & $-0,01$ &,- 01 \\
\hline $\begin{array}{l}\text { Spol x socialna } \\
\text { samopodoba }\end{array}$ & & & & & & & 0,02 & ,02 \\
\hline Spol x priljubljenost & & & & & & & 0,00 &,- 03 \\
\hline Spol x prijateljstvo & & & & & & & 0,00 &, 00 \\
\hline $\begin{array}{l}\text { Spol x zaznana opora } \\
\text { učiteljev }\end{array}$ & & & & & & & 0,01 &, 02 \\
\hline$\Delta R^{2}$ & & & & & & & &, 00 \\
\hline$R^{2}$ & & *** & & & & & & $* * *$ \\
\hline$F$ za spremembo $R^{2}$ & & & & & & & & \\
\hline
\end{tabular}

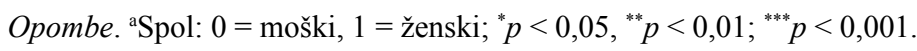

medtem ko so dekleta poročala o nekoliko višji stopnji odnosne viktimiziranosti. Glede slednjega je potrebno izpostaviti, da so razlike med spoloma $\mathrm{v}$ poročani odnosni viktimizaciji majhne; statistično značilnost spola kot napovednika odnosne viktimizacije gre tako pripisati predvsem velikosti vzorca, saj spol in starost ne pojasnjujeta variabilnosti $\mathrm{v}$ odnosni viktimizaciji. Rezultati naše raziskave so tako skladni $\mathrm{z}$ dosedanjimi ugotovitvami, da so fantje pogosteje udeleženi v neposrednih oblikah nasilja (Nansel idr., 2001), ne potrjujejo pa teze o večji vključenosti deklet v odnosno nasilje, saj smo ugotovile višjo stopnjo samoporočanega odnosnega nasilja pri fantih, razlike v odnosni viktimizaciji pa so med spoloma skoraj nične. Starost učencev se je izkazala kot pomemben napovednik vseh treh oblik nasilnega vedenja; starejši učenci so poročali o več izvajanja telesnega, besednega in odnosnega nasilja, ne pa tudi o višji stopnji doživljanja nasilja - ugotovitev je skladna $\mathrm{z}$ ugotovitvami nekaterih predhodnih raziskav (npr. Demaray in Malecki, 2003). Delež variance, ki ga pojasnjujejo demografski dejavniki, je najvišji za telesno in besedno nasilje, zelo nizek oziroma ničen je za besedno in odnosno viktimizacijo.
Izmed mer vrstniških odnosov učencev, ki so bile dodane v drugem koraku hierarhične regresijske analize, predstavlja zaznana opora vrstnikov najmočnejši napovednik vseh treh oblik viktimizacije: učenci, ki zaznavajo manj opore vrstnikov, poročajo o višji stopnji telesne, besedne in odnosne viktimizacije. Samopodoba na področju vrstniških odnosov prav tako negativno napoveduje vse tri oblike viktimizacije - učenci, ki se dojemajo kot manj učinkovite na področju odnosov z vrstniki, poročajo o višji stopnji telesne, besedne in odnosne viktimizacije, prav tako pa poročajo o višji stopnji izvajanja odnosnega nasilja. Nizka samopodoba je bila sicer v preteklih raziskavah prepoznana kot značilnost tako žrtev kakor tudi učencev, ki so hkrati nasilneži in žrtve medvrstniškega nasilja (O'Moore in Kirkham, 2001). S strani vrstnikov zaznana priljubljenost pozitivno napoveduje izvajanje vseh treh oblik nasilja; učenci, ki jih vrstniki zaznavajo kot bolj priljubljene v razredu, so tisti, ki v večji meri izvajajo telesno, besedno in odnosno nasilje. Obenem učenci, ki so bili s strani vrstnikov v manjši meri imenovani kot prijatelji, poročajo o več tako doživljanja kakor tudi izvajanja odnosnega nasilja. Zaznana opora s strani 
vrstnikov in visoka socialna samopodoba se torej kažeta kot pomembna varovalna dejavnika viktimizacije, priljubljenost kot pokazatelj socialne moči pa poveča verjetnost za izvajanje besednega in odnosnega, ne pa tudi telesnega nasilja. Te ugotovitve so v glavnem skladne $\mathrm{z}$ ugotovitvami predhodnih raziskav, ki so viktimizacijo in nasilno vedenje opredeljevale kot dvodimenzionalna konstrukta (npr. De Bruyn idr., 2010; Cook idr., 2010; Hodges idr., 1999; Veenstra idr., 2005) in potrjujejo sodobno paradigmo pojmovanja medvrstniškega nasilja kot izrazito socialnega pojava. Zanimiva je ugotovitev, da je odsotnost prijateljskih odnosov pomemben napovednik odnosne viktimizacije in nasilja: učenci torej $\mathrm{v}$ manjši meri vzpostavljajo prijateljske odnose s tistimi, ki so tako tarče kot izvajalci odnosnega nasilja. Prav tako rezultati naše raziskave kažejo, da so vrstniški odnosi v procesu besednega in odnosnega nasilja bolj pomemben dejavnik kot $\mathrm{v}$ procesu telesnega nasilja. To potrjuje tudi dejstvo, da je delež variance, ki ga pojasnjujejo mere vrstniških odnosov, za telesno viktimizacijo nižji kot za besedno in odnosno viktimizacijo, kjer je mogoče s temi merami pojasniti pretežen del celotne pojasnjene variance (17 \%). Ugotovitev je skladna s sodobnimi pojmovanji procesa medvrstniškega nasilja kot procesa doseganja in dokazovanja socialnega statusa (npr. Salmivalli in Peets, 2011), kar se zdi učinkoviteje dosegati skozi odnosno in besedno nasilje nad posamezniki z manj socialne moči v razredu kot pa s telesnim nasiljem. Delež $\mathrm{z}$ merami vrstniških odnosov pojasnjene variance je sicer za mere viktimizacije precej višji kot za mere nasilnega vedenja, kjer mere vrstniških odnosov pojasnjujejo odstotek (telesno in odnosno nasilje) oziroma dva odstotka variance (besedno nasilje). Zaključimo lahko torej, da so mere posameznikovih odnosov $\mathrm{v}$ razredu pomembnejše za razumevanje procesa viktimiziranosti kot za razumevanje nasilnega vedenja.

Del odgovora na vprašanje, kateri psihosocialni vidiki posameznikovega delovanja bi utegnili napovedovati nasilno vedenje, daje analiza tretjega sklopa napovednikov, v katerem smo dodali eno spremenljivko - s strani učenca zaznano oporo učiteljev. Ta se ni izkazala kot pomemben dejavnik telesne in odnosne viktimizacije in predstavlja zelo šibek pozitiven napovednik besedne viktimizacije, ne pojasnjuje pa dodatne variance $\mathrm{v}$ nobeni izmed oblik viktimizacije. Obenem je zaznana opora učiteljev pomemben negativen napovednik vseh treh oblik nasilnega vedenja: učenci, ki zaznavajo manj opore svojih učiteljev, poročajo o višji stopnji izvajanja telesnega, besednega in odnosnega nasilja. Odsotnost opore učiteljev torej na našem vzorcu v nasprotju s predhodnimi raziskavami (Cassidy, 2009) ne napoveduje medvrstniške viktimizacije, je pa pomemben napovednik nasilnega vedenja, ki pojasnjuje pomemben del variance $\mathrm{v}$ vseh treh oblikah nasilnega vedenja, ki ni pojasnjena $\mathrm{s}$ posameznikovim položajem v skupini. Ta ugotovitev je še posebej pomembna za načrtovanje ukrepov za preprečevanje in odzivanje na medvrstniško nasilje, saj kaže, da utegnejo imeti učitelji vpliv na preprečevanje oziroma zmanjševanje stopnje medvrstniškega nasilja ne le kot podporniki žrtev temveč tudi pomembne podporne osebe v odnosu do učencev, ki nasilje izvajajo.

Analize moderatorske vloge spola kažejo, da je odnos med nekaterimi psihosocialnimi značilnostmi učencev ter njihovo vključenostjo $\mathrm{v}$ vrstniško viktimizacijo oziroma nasilje spolno specifičen. Tako rezultati naše raziskave kažejo, da sta zaznana opora vrstnikov in socialna samopodoba pomembnejša dejavnika telesne viktimizacije pri fantih kot pri dekletih; fantje, ki zaznavajo manj opore vrstnikov in imajo nižjo socialno samopodobo, poročajo o več telesne viktimizacije. Pri dekletih zaznana opora vrstnikov in socialna samopodoba ne napovedujeta oziroma $v$ manjši meri napovedujeta telesno viktimizacijo, kar je najverjetneje pogojeno tudi $\mathrm{z}$ nizko stopnjo te oblike viktimizacije pri dekletih. Zaznana opora učiteljev predstavlja pomemben napovednik besedne viktimizacije le za dekleta; dekleta, ki zaznavajo višjo stopnjo opore učiteljev, poročajo o manj besedne viktimizacije. Zaznana opora učiteljev, ki samostojno zelo šibko napoveduje besedno viktimiziranost, se torej pri dekletih kaže kot pomemben varovalni dejavnik, pri fantih pa tega potenciala nima. Zanimiv je moderatorski učinek spola $\mathrm{v}$ odnosu med s strani vrstnikov zaznano priljubljenostjo in besedno viktimizacijo: zaznana priljubljenost pri fantih ni pomemben napovednik besedne viktimiziranosti, pri dekletih pa visoka priljubljenost pozitivno napoveduje samoporočano besedno viktimizacijo. Videti je torej, da se dekleta, ki so s strani drugih v razredu zaznana kot najbolj opazna in priljubljena, v vrstniških odnosih pogosteje zaznavajo kot žrtve besednega nasilja. Zaznana priljubljenost je konstrukt, ki se nanaša na vrstniške zaznave priljubljenosti, opaznosti in vpliva učencev $\mathrm{v}$ razredu; ti učenci niso nujno tudi sociometrično priljubljeni (LaFontana in Cillessen, 1999); pretekle raziskave (npr. Cillessen in Rose, 2005) ugotavljajo, da se zaznana priljubljenost bolj kot s sprejetostjo s strani vrstnikov povezuje $\mathrm{z}$ visoko stopnjo socialne moči ali celo odnosno agresivnostjo. Očitno je lahko tovrstna opaznost in vplivnost pri dekletih v obdobju zgodnjega mladostništva subjektivno doživeta tudi kot besedna viktimizacija; v tej luči lahko torej pri dekletih nižja stopnja priljubljenosti in vplivnosti $\mathrm{v}$ razredu predstavlja varovalni dejavnik za besedno viktimizacijo.

Analiza moderatorske vloge spola $\mathrm{v}$ odnosu med psihosocialnimi značilnostmi učencev in njihovim izvajanjem različnih oblik nasilja kaže, da je ta odnos spolno specifičen v primeru odnosa med zaznano oporo učiteljev in izvajanjem telesnega in besednega nasilja. Fantje, ki zaznavajo višjo stopnjo opore učiteljev, poročajo o nižji stopnji izvajanja telesnega in besednega nasilja. Varovalni potencial zaznane opore učiteljev, ki se kaže kot pomemben samostojen negativni napovednik za izvajanje vseh treh oblik medvrstniškega nasilja, je torej vsaj $\mathrm{v}$ obdobju zgodnjega mladostništva posebej pomemben za fante.

\section{Zaključki in smernice}

Kot ključna napovednika vseh treh oblik viktimizacije se torej kažeta nizka zaznana opora vrstnikov ter nizka socialna samopodoba; napovednik telesne in besedne viktimizacije je poleg tega še moški spol, nižja stopnja prijateljskih odnosov pa napoveduje odnosno viktimizacijo. Višja starost učencev ter nižja zaznana opora učiteljev napovedujeta vse tri oblike izvajanja nasilja nad vrstniki; poleg tega izvajanje odnosnega nasilja napovedujeta tudi nižja stopnja socialne samopodobe in manj prijateljskih odnosov, višja stopnja s strani vrstnikov zaznane priljubljenosti pa pozitivno napoveduje vse tri oblike 
izvajanja nasilja. Spol učencev se kaže kot moderator odnosov med zaznano oporo učiteljev ter med besedno viktimizacijo ter med telesnim in besednim nasiljem; zaznana opora učiteljev je tako varovalni dejavnik proti besedni viktimizaciji le za dekleta ter proti izvajanju besednega in telesnega nasilja le za fante. Fantje (ne pa tudi dekleta), ki zaznavajo manj opore vrstnikov in ki imajo nižjo socialno samopodobo, poročajo o več telesne viktimizacije; dekleta, ki jih vrstniki zaznavajo kot bolj priljubljene $\mathrm{v}$ razredu, poročajo o več besedne viktimizacije.

Rezultati raziskave načeloma nakazujejo, da so napovedniki različnih dimenzij znotraj konstrukta viktimizacije oziroma nasilnega vedenja dokaj podobni in da je, kadar želimo splošno mero doživljanja oziroma izvajanja medvrstniškega nasilja, meri viktimizacije in nasilja načeloma ustrezno operacionalizirati kot enodimenzionalni meri. Nekatere razlike $\mathrm{v}$ napovednikih za posamezne dimenzije (pri čemer zlasti izstopa odnosna viktimizacija/nasilje kot posredna oblika nasproti neposrednima oblikama besedne in telesne viktimizacije/nasilja) pa vendarle nakazujejo, da obstajajo subtilne razlike $\mathrm{v}$ napovednikih posameznih oblik viktimizacije in nasilnega vedenja, ki bi jih bilo smiselno dodatno osvetliti v prihodnjih raziskavah. Prav tako bi bilo v prihodnjih raziskavah smiselno vzdolžno preveriti morebitne razvojne spremembe $\mathrm{v}$ pomenu posameznih psihosocialnih značilnosti učencev za razvoj viktimizacije oziroma nasilnega vedenja v različnih razvojnih obdobjih. Glede na ugotovljeno ne povsem ustrezno konstruktno veljavnost Vprašalnika opisovanja samega sebe (SDQ II-S), ki tudi v slovenskem prostoru predstavlja pogosto uporabljano mero samopodobe mladostnikov, bi bilo v prihodnjih raziskavah smiselno tudi sistematično preveriti veljavnost slovenske različice tega vprašalnika.

Ključna omejitev, ki jo je potrebno upoštevati pri interpretaciji izsledkov naše raziskave ter pri izpeljevanju praktičnih implikacij, je prečni raziskovalni načrt, ki ne omogoča zaključkov o naravi odnosa med psihosocialnimi značilnostmi učencev ter njihovo vključenostjo $\mathrm{v}$ proces medvrstniškega nasilja bodisi kot žrtev bodisi kot nasilnež. Prav tako je potrebno upoštevati, da sta viktimizacija in nasilno vedenje neodvisni dimenziji, ki lahko pri posamezniku soobstajata; $\mathrm{z}$ analizami, ki smo jih uporabili v naši raziskavi, nismo ugotavljali psihosocialnih značilnosti učencev, ki so hkrati nasilneži in žrtve. Slednje bi bilo vsekakor zelo pomembno nasloviti v prihodnjih raziskavah. Vendarle pa predstavljajo ugotovitve raziskave pomembno izhodišče tako za načrtovanje preventivnih dejavnosti na področju medvrstniškega nasilja kot za oblikovanje smiselnih smernic za delo $\mathrm{z}$ učenci, ki so bodici žrtve bodisi izvajalci različnih oblik medvrstniškega nasilja. Zaznana opora vrstnikov se je v naši raziskavi pokazala kot ključni varovalni dejavnik viktimizacije, kar potrjuje sodobna pojmovanja vrstniške skupine kot ključnega dejavnika razvoja dinamike medvrstniškega nasilja. Ukrepi, ki temeljijo na spodbujanju spoštljivih in skrbnih vrstniških odnosov, so najbolj učinkoviti v najzgodnejših letih šolanja, ko se socialni odnosi in pravila vedenja v razredu še vzpostavljajo, obenem pa je neposreden vpliv učitelja na učence $\mathrm{v}$ tem obdobju $\mathrm{v}$ primerjavi s kasnejšim obdobjem mladostništva precejšen.
Salmivalli (2014) navaja nekaj ukrepov, ki so se izkazali kot smiselni načini preprečevanja medvrstniškega nasilja in s katerimi lahko učitelj učence opremi s spretnostmi za konstruktivno odzivanje na medvrstniško nasilje: (1) skozi razredne diskusije, igre vlog in posredovanje povratnih informacij o njihovem vedenju $\mathrm{v}$ situacijah medvstniškega nasilja ozaveščati učence o vlogi, ki jo imajo opazovalci $\mathrm{v}$ procesu medvrstniškega nasilja; mnogi učenci so namreč prepričani, da medvrstniško nasilje, ki se dogaja v razredu, ni njihova stvar, dokler sami ne sodelujejo v njem; (2) spodbujati empatijo do žrtev medvrstniškega nasilja; skozi različne dejavnosti (filmi, mladinska literarna dela, igre vlog, odzivanje na vsakodnevne konfliktne situacije v razredu) razvijati zmožnost učencev, da razumejo perspektivo žrtve ter (3) učence poučiti o varnih strategijah, s katerimi lahko podprejo žrtev.

Prav tako je za ustrezno načrtovanje preprečevanja in odzivanja na medvrstniško nasilje pomembna ugotovitev, da predstavlja zaznana opora učiteljev pomemben dejavnik v razvoju dinamike medvrstniškega nasilja. Ne glede na naravo povezanosti med zaznavanjem podpornega odnosa $\mathrm{z}$ učiteljem in izvajanjem nasilnega vedenja je utemeljeno predpostaviti, da je lahko podporen odnos z učiteljem dejavnik, ki zmanjša verjetnost izvajanja medvrstniškega nasilja. Ukrepi, usmerjeni $\mathrm{v}$ zmanjšanje stopnje medvrstniškega nasilja na šoli, naj bi bili tako usmerjeni tudi $\mathrm{v}$ oporo učiteljem pri vzpostavljanju pozitivnih, podpornih odnosov tudi z učenci z višjo stopnjo motečega, socialno nezaželenega vedenja na način, ki bi krepil njihovo zmožnost uporabe globinskih strategij čustvenega dela oziroma brezpogojnega sprejemanja v odnosu do teh učencev.

\section{Literatura}

Aiken, L. S. in West, S. G. (1991). Multiple regression: Testing and interpreting interactions. Newbury Park, CA, ZDA: Sage Publications.

Boulton, M., Trueman, M., Chau, C., Whitehand, C. in Amatya, K. (1999). Concurrent and longitudinal links between friendship and peer victimization: Implications for befriending interventions. Journal of Adolescence, $22,461-466$.

Bouman, T., van der Meulen, M., Goossens, F. A., Olthof, T., Vermande, M. M. in Aleva, E. A. (2012). Peer and self-reports of victimization and bullying: Their differential association with internalizing problems and social adjustment. Journal of School Psychology, 50(6), 759-774.

Bradshaw, C. P., Sawyer, A. L. in O’Brennan, L. M. (2009). A social disorganization perspective on bullying-related attitudes and behaviors: The influence of school context. American Journal of Community Psychology, 43, 204-220.

Card, N. A., Stucky, B. D., Sawalani, G. M. in Little, T. D. (2008). Direct and indirect aggression during childhood and adolescence: A metaanalytic review of intercorrelations, gender differences, and relations to maladjustment. Child Development, 79, 1185-1229. 
Cassidy, T. (2009). Bullying and victimisation in school children: The role of social identity, problem-solving style, and family and school context. Social Psychology of Education, 12, 63-76.

Cillessen, A. H. N. in Rose, A. J. (2005). Understanding popularity in the peer system. Current Directions in Psychological Science, 14(2), 102-105.

Cook, C., Williams, K. R., Guerra, N. G., Kim, T. in Sadek, S. (2010). Predictors of bullying and victimization in childhood and adolescence: A meta-analytic investigation. School Psychology Quarterly, 25, 65-83.

Crick, N. R. in Grotpeter, J. K. (1995). Relational aggression, gender, and social-psychological adjustment. Child Development, 66, 710-722.

De Bruyn, E. H., Cillessen, A. H. N. in Wissink, I. B. (2010). Associations of peer acceptance and perceived popularity with bullying and victimization in early adolescence. Journal of Early Adolescence, 30, 543-566.

Demaray, M. K. in Malecki, C. K. (2003). Perceptions of the frequency and importance of social support by students classified as victims, bullies, and bully/victims in an urban middle school. School Psychology Review, 32(3), 471-489.

Di Stasio, M. R., Savage, R. in Burgos, G. (2016). Social comparison, competition and teacher-studentrelationships in junior high school classrooms predicts bullying and victimization. Journal of Adolescence, 53, 207-216.

Guérin, F., Marsh, H. W. in Famose, J. P. (2003). Construct validation of the Self-Description Questionnaire II with a French sample. European Journal of Psychological Assessment, 19, 142-150.

Hodges, E. V. E., Boivin, M., Vitaro, F. in Bukowski, W. (1999). The power of friendship: Protection against an escalating cycle of peer victimization. Developmental Psychology, 35, 94-101.

Hox, J. (2010). Multilevel analysis: Techniques and applications. Mahwah, NJ, ZDA: Lawrence Erlbaum.

Johnson, D.W., Johnson, R. in Anderson, D. (1983). Social interdependence and classroom climate. Journal of Psychology, 114, 135-142.

Karlsson, E., Stickley, A., Lindblad, F., Schwab-Stone, M. in Ruchkin, V. (2014). Risk and protective factors for peer victimization: A 1-year follow-up study of urban American students. European Child \& Adolescent Psychiatry, 23(9), 773-781.

Kärnä, A., Voeten, M., Little, T. D., Poskiparta, E., Kaljonen, A. in Salmivalli, C. (2011). A large-scale evaluation of the KiVa antibullying program: Grades 4-6. Child Development, 82, 311-330.

Khoury-Kassabri, M., Benbenishty, R., Astor, R. A. in Zeira, A. (2004). The contributions of community, family, and school variables to student victimization. American Journal of Community Psychology, 34, 187-204.

Kochenderfer-Ladd, B. in Pelletier, M. E. (2008). Teachers' views and beliefs about bullying: Influences on classroom management strategies and students' coping with peer victimization. Journal of School Psychology, 46, 431-453.
Košir, K., Horvat, M., Aram, U. in Jurinec, N. (2016). Is being gifted always an advantage? Peer relations and self-concept of gifted students. High Ability Studies, 27, 129-148.

Košir, K., Klasinc, L, Pivec, T., Špes, T., Cankar, G. in Horvat, M. Predictors of self-reported and peer-reported victimization and bullying behavior in early adolescents. The role of school, classroom and individual factors. Oddano v publikacijo.

Košir, K. in Pečjak, S. (2007). Dejavniki, ki se povezujejo s socialno sprejetostjo $\mathrm{v}$ različnih obdobjih šolanja. Psihološka obzorja, 16, 49-73.

Košir, K. in Tement, S. (2014). Teacher-student relationship and academic achievement: A cross-lagged longitudinal study on three different age groups. European Journal of Psychology of Education, 29, 409-428.

LaFontana, K. M. in Cillessen, A. H. N. (1999). Children's interpersonal perceptions as a function of sociometric and peer percieved popularity. The Journal of Genetic Psychology, 160, 225-241.

Lennings, C. J. in Lawer, J. R. (1992). Self-concept: A study of Marsh's self description questionnaire (SDQ-2). Social Behavior and Personality, 20, 243-246.

Ma, X. (2002). Bullying in middle school: Individual and school characteristics of victims and offenders, school effectiveness and school improvement. An International Journal of Research, Policy and Practice, 13, 63-89.

Marsh, H. W. (1992). Self Description Questionnaire (SDQ) II: A theoretical and empirical basis for the measurement of multiple dimensions of adolescent self-concept: An interim test manual and a research monograph. Novi Južni Wales, Avstralija: University of Western Sydney, Faculty of Education.

Marsh, H. W., Nagengast, B., Morin, A. J., Parada, R. H., Craven, R. G. in Hamilton, L. R. (2011). Construct validity of the multidimensional structure of bullying and victimization: An application of exploratory structural equation modeling. Journal of Educational Psychology, 103(3), 701-732.

Menesini, E. in Salmivalli, C. (2017). Bullying in schools: The state of knowledge and effective interventions. Psychology, Health \& Medicine, 22, 240-253.

Nansel, T. R., Overpeck, M., Pilla, R. S., Ruan, J. W., Simons-Morton, B. in Scheidt, P. (2001). Bullying behaviors among US youth: Prevalence and association with psychosocial adjustment. Journal of the American Medical Association, 285, 2094-2100.

Nocentini, A., Menesini, E. in Salmivalli, C. (2013). Level and change of bullying behavior during high school: A multilevel growth curve analysis. Journal of Adolescence, 36, 495-505.

Olthof, T., Goossens, F. A., Vermande, M. M., Aleva, E. A. in van der Maulen, M. (2011). Bullying as strategic behavior: Relations with desired and acquired dominance in the peer group. Journal of School Psychology, 49, 339-359.

Olweus, D. (1993). Bullying at school: What we know and what we can do. Malden, MA: Blackwell. 
O'Moore, M. in Kirkham, C. (2001). Self-esteem and its relationship to bullying behaviour. Aggressive Behavior, 27(4), 269-283.

Orpinas, P. in Horne, A. M. (2006). Bullying prevention: Creating a positive school climate and developing social competence. Washington, DC, ZDA: American Psychological Association.

Parada, R. (2000). Adolescent Peer Relations Instrument: A theoretical and empirical basis for the measurement of participant roles in bullying and victimisation of adolescence: An interim test manual and a research monograph: A test manual. Penright South, DC, Autstralia: Publication Unit, Self-concept Enhancement and Learning Facilitation (SELF) Research Centre, University of Western Sydney.

Perry, D. G., Kusel, S. J. in Perry, L. C. (1988). Victims of peer aggression. Developmental Psychology, 24(6), 807-814.

Peugh, J. L. (2010). A practical guide to multilevel modeling. Journal of School Psychology, 48(1), 85-112.

Raudenbush, S.W., Bryk, A.S, \& Congdon, R. (2011). HLM 7.00 for Windows [Computer software]. Lincolnwood, IL, ZDA: Scientific Software International.

$\mathrm{R}$ Core Team (2018). $R$ : A language and environment for statistical computing. $\mathrm{R}$ Foundation for Statistical Computing, Vienna, Austria. URL: https://www.Rproject.org/

Rosseel, I. (2012). lavaan: an R package for structural equation modelling and more. Journal of Statistical Software, 48, $1-36$.

Saarento, S., Boulton, A. J. in Salmivalli, C. (2015). Reducing bullying and victimization: Student- and classroomlevel mechanisms of change. Journal of Abnormal Child Psychology, 43, 61-76.

Saarento, S., Garandeau, C. F. in Salmivalli, C. (2015). Classroom- and school-level contributions to bullying and victimization: A review. Journal of Community \& Applied Social Psychology, 25, 204-218.

Saarento, S., Kärnä, A., Hodges, E. V. in Salmivalli, C. (2013). Student-, classroom-, and school-level risk factors for victimization. Journal of School Psychology, 51, 421-434.

Sainio, M., Veenstra, R., Huitsing, G. in Salmivalli, C. (2011). Victims and their defenders: A dyadic approach. International Journal of Behavioral Development, 35, 144-151.

Salmivalli, C. (2014). Participant roles in bullying: How can peer bystanders be utilized in interventions? Theory Into Practice, 53(4), 286-292.

Salmivalli, C., Huttunen, A. in Lagerspetz, K. (1997). Peer networks and bullying in schools. Scandinavian Journal of Psychology, 38, 305-312.

Salmivalli, C. in Kaukiainen, A. (2004). »Female aggression« revisited: Variable-and-person-centered approaches to studying gender differences in direct and indirect aggression. Aggressive Behavior, 30, 158-163.

Salmivalli, C., Lagerspetz, K., Björkqvist, K., Österman, K. in Kaukiainen, A. (1996). Bullying as a group process: Participant roles and their relations to social status within the group. Aggressive Behavior, 22(1), 1-15.
Salmivalli, C. in Peets, K. (2011). Bullies, victims, and bully-victim relationships in middle childhood and early adolescence. V K. H. Rubin, W. M. Bukowski in B. Laursen (ur.), Handbook of peer interactions, relationships, and groups (str. 322-340). New York, NY, ZDA: Guilford Press.

Salmivalli, C., Voeten, M. in Poskiparta, E. (2011). Bystanders matter: Associations between reinforcing, defending, and the frequency of bullying behavior in classrooms. Journal of Clinical Child \& Adolescent Psychology, 40, 668-676.

Sanders, C. E. in Phye. G. D. (ur.) (2004). Bullying: Implications for the classroom. San Diego: Elsavier Academic Press.

Vaillancourt, T., Hymel, S. in McDougall, P. (2003). Bullying is power: Implications for school-based intervention strategies. Journal of Applied Social Psychology, 19, 157-176.

Veenstra, R., Lindenberg, S., Oldehinkel, A. J., De Winter, A. F., Verhulst, F. C. in Ormel, J. (2005). Bullying and victimization in elementary schools: A comparison of bullies, victims, bully/victims, and uninvolved preadolescents. Developmental Psychology, 41, 672-682. 